\title{
Creep of High-Purity Nickel
}

\author{
William D. Jenkins, Thomas G. Digges, and Carl R. Johnson
}

\begin{abstract}
A study was made of the creep behavior in tension at $300^{\circ}, 700^{\circ}, 900^{\circ}$, and $1,200^{\circ} \mathrm{F}$ of initi $1 \mathrm{y}$ annealed high-purity nickel. Discontinuous flow was observed in each of the three stages of creep, and it was affected by temperature, strain rate, and prior-strain history. The phenomenon of strain aging was especially prominent at $300^{\circ} \mathrm{F}$ as manifested by the attainment of an appreciable creep life in specimens stressed in excess of the tensile strength at this temperature. The experimental results are analyzed in terms of the past and present theories of deformation of metals. Strain hardening, recovery, and the initiation, propagation, and types of fractures obtained during creep are further evaluated by means of true-stress-truestrain and hardness data obtained at room temperature and by metallographic examination of the fractured specimens.
\end{abstract}

\section{Introduction}

Numerous equaticus have been proposed by analysts of creep data is descriptive of the extensiontime relationship in the creep of metallic materials. The equations are modified and new ones are proposed as experimental results are accumulated. To date, however, no theoretical treatment of the complete extension-time relation is universally accepted, and there is still need for additional precise data from experiments carried nut under accurately controlled conditions. The interrelation of strain hardening, recovery, and recrystallization are not fully understood, and the important role of the thermal-mechanical history on creep behavior has not been generally recognized. Any adequate physical theory of the mechanism of plastic flow in creep must account for the influence of all these factors.

The present tests on high-purity nickel were made as one phase of a project to study the mechanism of creep in high-purity polycrystalline metals and to evaluate the creep behavior of these metals in comparison with binary alloys of such metals. The comprehensive program includes a study of the creep characteristics of high-purity copper, high-purity nickel, and alloys of these two metals. As previously pointed out $[1],{ }^{1}$ the relatively low temperatures at which creep may occur in each of these metals, the unlimited solid solubility of the two metals in each other, the availability of commercial metal of high purity, and the wide industrial applications of both the metals and alloys made the binary system an attractive one for use in the present investigation.

The present paper is concerned with the results of creep tests made on high-purity nickel at $300^{\circ}, 700^{\circ}$, $900^{\circ}$, and $1,200^{\circ} \mathrm{F}$, the influence of rate of loading to selected creep stresses on creep behavior, and the effect of prior-strain history on the tensile properties at room temperature of the nickel. Contour and hardness surveys were also made on specimens fractured in creep and on specimens fractured in tension at room temperature, and the microstructures were correlated with creep and tensile behavior.

1 Figures in brackets indicate the literature references at the end of this paper.

\section{Previous Investigations}

The results of creep and other tests made at the National Bureau of Standards on high-purity copper, both initially as annealed and as cold-worked to various amounts, and on annealed high-purity nickel are presented in several publications [1, 2, 3, 4]. The results of tension tests made at temperatures ranging from $-320^{\circ}$ to $+1,500^{\circ} \mathrm{F}$ on the same lot of high-purity nickel [3] as that used in the present creep tests showed irregularities in some of the tensile properties at temperatures of about $80^{\circ}$ to $300^{\circ} \mathrm{F}$ and $500^{\circ}$ to $700^{\circ} \mathrm{F}$; strain aging occurred in the range $80^{\circ}$ to $300^{\circ} \mathrm{F}$; recovery and recrystallization predominated in specimens fractured at $1,200^{\circ}$ or $1,500^{\circ} \mathrm{F}$.

Several comprehensive summaries and appraisals of the existing theories of creep have been recently published [5, 6]. Hazlett and Parker [7] included the results of some constant-stress creep tests on high-purity nickel in their discussion of the nature of the creep curve. No attempt will be made, therefore, to completely review the abundant literature on the deformation of metals, but reference will be made to selected publications that are closely related to the results given in subsequent sections of this paper.

\section{Material, Apparatus, and Procedures}

The nickel was prepared by induction melting, and all bars were processed from one 14 - by 14 - by 60 -in. ingot. This ingot was milled, then forged to 8- by 8 -in. blooms, and hot-rolled to $2 \frac{1}{2}$-in. square billets. The billets were then hot-rolled to $7 / 8$-in.-diameter bars and annealed $16 \mathrm{hr}$ at $1,100^{\circ} \mathrm{F}$, followed by $8 \mathrm{hr}$ at $1,000^{\circ} \mathrm{F}$. The average grain diameter was $0.045 \mathrm{~mm}$ in the above condition as supplied by the manufacturer. All the specimens used in the creep tests except two were prepared from the same bar, designated as $\mathrm{A}$ in tables 1, 2, and 3; the two specimens prepared from bar $\mathrm{E}$ were used for check purposes. Chemical, spectrochemical, and vacuumfusion analyses were made on specimens prepared from bar $\mathrm{A}$, and the results (percentage by weight) were as follows: $99.85 \mathrm{Ni}, 0.009 \mathrm{Cu}, 0.04 \mathrm{Fe}, 0.03$ $\mathrm{Mn}, 0.11 \mathrm{Si}, 0.007 \mathrm{C}, 0.002 \mathrm{~S},<0.01 \mathrm{Co}, 0.001 \mathrm{O}_{2}$, $0.001 \mathrm{~N}_{2}$, and $0.0002 \mathrm{H}_{2}$. 
TARLE 1. Summary of conditions used and results of creep tests on high-purity nickel, initially as annealed

Rate of loading, 5,330 lb/in.2, added at 1-hr intervals.

\begin{tabular}{|c|c|c|c|c|c|c|c|c|c|c|c|c|c|c|}
\hline \multicolumn{2}{|c|}{ Test } & \multirow{2}{*}{$\begin{array}{c}\text { Nomi- } \\
\text { nal } \\
\text { creep } \\
\text { stress a }\end{array}$} & \multirow{2}{*}{$\begin{array}{l}\text { Plastic } \\
\text { exten- } \\
\text { sion } \\
1 \text { hr. } \\
\text { after } \\
\text { appli- } \\
\text { cation } \\
\text { of load }\end{array}$} & \multirow{2}{*}{$\begin{array}{l}\text { Plastic } \\
\text { exten- } \\
\text { sion, } \\
\text { inter- } \\
\text { cept } \\
\text { at zero } \\
\text { time }\end{array}$} & \multirow{2}{*}{$\begin{array}{l}\text { A verage } \\
\text { creep rate, } \\
\text { second } \\
\text { stage }\end{array}$} & \multicolumn{3}{|c|}{ Beginning of third stage } & \multicolumn{5}{|c|}{ End of test } & \multirow[b]{2}{*}{ Remarks } \\
\hline Number & $\begin{array}{l}\text { Tem- } \\
\text { per'- } \\
\text { ture }\end{array}$ & & & & & Time & $\begin{array}{l}\text { Plastic } \\
\text { exten- } \\
\text { sion }\end{array}$ & $\begin{array}{l}\text { True } \\
\text { stress b }\end{array}$ & Time & $\begin{array}{l}\text { Plostic } \\
\text { exten- } \\
\text { sion }\end{array}$ & $\begin{array}{l}\text { Reduc- } \\
\text { tion of } \\
\text { area }\end{array}$ & $\begin{array}{c}\log _{e} \\
\left(A_{0} / A_{f}\right)^{\circ}\end{array}$ & $\begin{array}{l}\text { True } \\
\text { stress }\end{array}$ & \\
\hline$A-5 \ldots$ & $\begin{array}{l}{ }^{\circ} \mathrm{F} \\
300\end{array}$ & $\begin{array}{l}\text { lb/in. }{ }^{2} \\
37,330\end{array}$ & $\begin{array}{l}\% \\
11.7\end{array}$ & $\begin{array}{l}\% \\
11.9\end{array}$ & $\begin{array}{c}\% 1,000 h r \\
0\end{array}$ & $h r$ & $\%$ & $l b / i n .^{2}$ & $\begin{array}{c}h r \\
1,485\end{array}$ & $\begin{array}{c}\% \\
11.9\end{array}$ & $\begin{array}{l}\% \\
10\end{array}$ & & $\begin{array}{l}l b / i n .^{2} \\
37,800\end{array}$ & Test stopped in sec- \\
\hline$A-9$ & 300 & 42,660 & 21.3 & 21.7 & 0.0007 & & & & 3,798 & 21.8 & 18 & & 52,000 & Do. \\
\hline$A-4$ & 300 & 45,000 & 29. 2 & 32.0 & .0011 & & & & 8,070 & 32. 03 & 24 & & 59,400 & Do. \\
\hline $\begin{array}{l}\mathrm{A}-12 \ldots \\
\mathrm{A}-16 \ldots\end{array}$ & $\begin{array}{l}300 \\
300\end{array}$ & $\begin{array}{l}45,500 \\
46,000\end{array}$ & $\begin{array}{l}31.0 \\
37.5\end{array}$ & $\begin{array}{l}34.5 \\
35.4\end{array}$ & $2,100^{.01}$ & 2.66 & 41.1 & 64,900 & $\begin{array}{l}6,403 \\
3.6\end{array}$ & $\begin{array}{l}34.56 \\
69.5\end{array}$ & ${ }_{87.6}^{26}$ & 2.08 & $\begin{array}{r}61,200 \\
370,800\end{array}$ & $\begin{array}{l}\text { Do. } \\
\text { Tested to complete }\end{array}$ \\
\hline & & & & & & & & & & & & & & fracture. \\
\hline$A-17$ & 700 & 16,000 & 1. 78 & 3. 65 & 0.30 & & & & 3,910 & 4. 84 & 4. 6 & & 23,700 & Test stopped in sec- \\
\hline A-11.. & 700 & 21,330 & 4. 7 & 16.9 & 1.6 & 9,800 & 32.5 & 28,400 & 21,047 & 101 & 93.0 & 2. 67 & 306,600 & Tested to complete \\
\hline$A-10 \ldots$ & 700 & 26,670 & 9.4 & 15.0 & 33.3 & 690 & 38 & 36,800 & 1,015 & 99.5 & 92.3 & 2. 56 & 346,400 & $\begin{array}{l}\text { Tracture. } \\
\text { Do. }\end{array}$ \\
\hline $\mathrm{A}-15$ & 700 & 29,335 & 12.5 & 16.6 & 120 & 127 & 32 & 38,700 & 207 & 91 & 93.4 & 2. 72 & 444,700 & Do. \\
\hline$A-7 \ldots$ & 700 & 32,000 & 21.5 & 22.3 & 1,020 & 14.5 & 37 & 43,800 & 22.1 & 73 & 92.9 & 2.65 & 454,100 & Do. \\
\hline$A-13 \ldots$ & 900 & 10,670 & 1. 02 & 7.10 & 1. 52 & & & & 4,004 & 13. 26 & 11.8 & & 12,100 & Test stopped in sec- \\
\hline$A-8 \ldots$ & 900 & 13,335 & 2.3 & 9. 7 & 7.35 & & & & 2,138 & 25.3 & 20 & & 16,700 & Do. \\
\hline & 900 & 16,000 & 2.8 & 13.0 & 20.1 & 960 & 33.5 & 21,400 & 1,870 & 60.6 & 42 & & 28,000 & Test stopped in third \\
\hline A-14... & 900 & 18,670 & 8.9 & 14. 0 & 238 & 92 & 36 & 25,400 & 153 & 107.5 & 95.8 & 3.14 & 443,400 & Tested to complete \\
\hline$A-18$ & 900 & 20,000 & 12.3 & 17.5 & 620 & 34 & 39 & 27,800 & 57.1 & 102.5 & 95.9 & 3. 19 & 484,500 & Do. \\
\hline A $22 \ldots$ & 1,200 & 4,010 & 0.07 & 0.94 & 10.5 & 370 & 4.5 & 4,200 & 6,800 & 66 & 47.1 & 0.64 & 7,600 & Tested to complete \\
\hline $\begin{array}{l}\mathrm{A}-21 \ldots \ldots \\
\mathrm{A}-20 \ldots \ldots\end{array}$ & $\begin{array}{l}1,200 \\
1,200\end{array}$ & $\begin{array}{l}6,670 \\
9,330\end{array}$ & $\begin{array}{l}1.6 \\
5.1\end{array}$ & $\begin{array}{l}4.4 \\
6.5\end{array}$ & $\begin{array}{l}62.5 \\
500\end{array}$ & $\begin{array}{l}82 \\
20\end{array}$ & $\frac{9.5}{17}$ & $\begin{array}{r}7,300 \\
10,900\end{array}$ & $\begin{array}{c}224 \\
32.3\end{array}$ & $\begin{array}{l}87 \\
91\end{array}$ & $\begin{array}{l}98.1 \\
97.4\end{array}$ & $\begin{array}{l}\text { 3. } 96 \\
\text { 3. } 66\end{array}$ & $\begin{array}{l}349,400 \\
364,000\end{array}$ & $\begin{array}{l}\text { Do. } \\
\text { Do. }\end{array}$ \\
\hline
\end{tabular}

a The nominal stress is defined as the stress obtained by dividing the current load by the original cross-sectional area of the specimen.

b The true stress is defined as the stress obtained by dividing the current load by the current minimum cross-sectional area of the specimen.

- $A_{0} / A_{f}$ is a ratio; the value $A_{0}$ being the initial cross-sectional area of the specimen, and the value $A_{\mathrm{f}}$ being the minimum cross-sectional area of the specimen after fracture.

TABLE 2. Effect of rate of loading on creep of high-purity nickel, initially as annealed

\begin{tabular}{|c|c|c|c|c|c|c|c|c|c|c|c|c|c|c|c|c|c|c|c|}
\hline \multirow[b]{3}{*}{ Test } & \multicolumn{19}{|c|}{ Creep behavior at $300^{\circ} \mathrm{F}$ and at indicated stresses } \\
\hline & \multicolumn{4}{|c|}{$37,330 \mathrm{lb} / \mathrm{in} .{ }^{2}$} & \multicolumn{3}{|c|}{$42,660 \mathrm{lb} / \mathrm{in} .{ }^{2}$} & \multicolumn{3}{|c|}{$45,000 \mathrm{lb} / \mathrm{in}^{2}$} & \multicolumn{3}{|c|}{$45,500 \mathrm{lb} / \mathrm{in}^{2}{ }^{2}$} & \multicolumn{3}{|c|}{$46,000 \mathrm{lb} / \mathrm{in} .^{2}$} & \multicolumn{3}{|c|}{$46,500 \mathrm{lb} / \mathrm{in} .^{2}$} \\
\hline & $\begin{array}{c}\text { Exten- } \\
\text { sion } \\
\text { prior } \\
\text { to ap- } \\
\text { plica- } \\
\text { tion of } \\
\text { this } \\
\text { stress }\end{array}$ & \begin{tabular}{c|c} 
Time & $\mathrm{E}$ \\
at & $\mathrm{si}$ \\
this & el \\
stress & te \\
& $\mathrm{s}$
\end{tabular} & \begin{tabular}{c|c} 
Exten- & \\
sion at & $\mathrm{c}$ \\
end of & $\mathrm{r}$ \\
test at & $\mathrm{r}$ \\
this & at \\
stress & $\mathrm{S}$
\end{tabular} & $\begin{array}{l}\text { Mean } \\
\text { creep } \\
\text { rate a } \\
\text { at this } \\
\text { stress }\end{array}$ & $\begin{array}{c}\text { Mean } \\
\text { creep } \\
\text { rate at } \\
\text { this } \\
\text { stress }\end{array}$ & $\begin{array}{l}\text { Time } \\
\text { at } \\
\text { this } \\
\text { stress }\end{array}$ & $\begin{array}{l}\text { Exter } \\
\text { sion } \\
\text { at en } \\
\text { of tes } \\
\text { at thi } \\
\text { stres: }\end{array}$ & \begin{tabular}{l|c}
$n-$ & Mear \\
n & creep \\
st & rate a \\
st & this \\
ss & stress
\end{tabular} & \begin{tabular}{l|c} 
nn & Time \\
p & at \\
at & this \\
s & stress \\
ss &
\end{tabular} & \begin{tabular}{c|c} 
Exten- \\
sion at \\
end of \\
test at \\
this \\
stress
\end{tabular} & $\begin{array}{l}\text { Mean } \\
\text { creep } \\
\text { rate at } \\
\text { this } \\
\text { stress }\end{array}$ & \begin{tabular}{|c|c|} 
Time \\
at \\
this \\
stress
\end{tabular} & $\begin{array}{l}\text { Exten- } \\
\text { sion } \\
\text { at end } \\
\text { of test } \\
\text { at this } \\
\text { stress }\end{array}$ & $\begin{array}{l}\text { Mean } \\
\text { creep } \\
\text { rate at } \\
\text { this } \\
\text { stress }\end{array}$ & \begin{tabular}{c|c} 
Time & E \\
at & a \\
this & 0 \\
stress & a \\
& s
\end{tabular} & $\begin{array}{l}\text { Exten- } \\
\text { sion } \\
\text { at end } \\
\text { of test } \\
\text { at this } \\
\text { stress }\end{array}$ & $\begin{array}{l}\text { Mean } \\
\text { creep } \\
\text { rate at } \\
\text { this } \\
\text { stress }\end{array}$ & $\begin{array}{l}\text { Time } \\
\text { at } \\
\text { this } \\
\text { stress }\end{array}$ & $\begin{array}{l}\text { Exten- } \\
\text { sion at } \\
\text { end of } \\
\text { test at } \\
\text { this } \\
\text { stress }\end{array}$ \\
\hline \multirow[t]{3}{*}{$\begin{array}{l}A-5 \ldots \\
A-9 \ldots \\
A-4 \ldots \\
A-12\end{array}$} & $\begin{array}{l}\% \\
7.496 \\
8.02 \\
8.53 \\
8.53\end{array}$ & $\begin{array}{c}h r \\
1482.8 \\
1 \\
1 \\
1\end{array}$ & \begin{tabular}{c|c}
$\%$ & $\%$ \\
11.875 & \\
12.352 & 4 \\
13.00 & 4 \\
13.45 & 4
\end{tabular} & \begin{tabular}{c|c}
$o / 1,000$ & $q$ \\
$h r$ & 9 \\
2.95 & 432 \\
4740 & \\
4920 &
\end{tabular} & $\begin{array}{c}\% / 1,000 \\
h r \\
4925 \\
2.49 \\
8547 \\
8051\end{array}$ & $\begin{array}{r}\text { hr } \\
1 \\
3798 \\
1 \\
1\end{array}$ & $\begin{array}{ll} & \% \\
1 & 16.80 \\
8 & 21.78 \\
1 & 21.54 \\
1 & 21.50\end{array}$ & \begin{tabular}{|c|c} 
& $\% / 1,00$ \\
30 & $h r$ \\
87 & 3. \\
57 & 1. \\
501 & 1. \\
\end{tabular} & \begin{tabular}{c|c} 
& \multicolumn{1}{c}{$h r$} \\
76 & 2249.3 \\
31 & 2833 \\
30 & 8070
\end{tabular} & $\begin{array}{l}\% \\
25.257 \\
25.502 \\
32.029\end{array}$ & \begin{tabular}{|c|c|} 
& $\% / 1,000$ \\
& $h r$ \\
7 & 0.33 \\
2 & .044 \\
9 & .004 \\
- & 2.04
\end{tabular} & \begin{tabular}{l|c|}
0 & $h r$ \\
& 3170.8 \\
4 & 2037.8 \\
44 & 2496.5 \\
& 6403.5
\end{tabular} & \begin{tabular}{l}
\multicolumn{1}{l}{$\%$} \\
26.315 \\
25.592 \\
32.04 \\
34.56
\end{tabular} & $\begin{array}{c}\% / 1,000 \\
h r \\
0.02 \\
.38 \\
.023 \\
.019\end{array}$ & \begin{tabular}{c|}
$h r$ \\
3982.3 \\
3191.5 \\
1560.8 \\
2640.5
\end{tabular} & \begin{tabular}{c|c|}
$\%$ & \\
26.395 \\
26.812 \\
32.076 \\
34.610
\end{tabular} & $\begin{array}{c}\% / 1,000 \\
h r \\
0.44 \\
.37 \\
2.61 \\
0.75\end{array}$ & $\begin{array}{c}h r \\
2904.8 \\
3841.5 \\
1032.8 \\
4552.5\end{array}$ & $\begin{array}{c}\% \\
27.679 \\
28.219 \\
34.777 \\
38.046\end{array}$ \\
\hline & \multicolumn{3}{|c|}{$47,000 \mathrm{lb} / \mathrm{in}^{2}$} & \multicolumn{4}{|c|}{$47,500 \mathrm{lb} / \mathrm{in}^{2}$} & \multicolumn{3}{|c|}{$48,000 \mathrm{lb} / \mathrm{in}^{2}{ }^{2}$} & \multicolumn{5}{|c|}{ Fracture } & \multirow{2}{*}{\multicolumn{4}{|c|}{ Remarks }} \\
\hline & $\begin{array}{l}\text { Mean } \\
\text { creep } \\
\text { rate at } \\
\text { this } \\
\text { stress }\end{array}$ & $\begin{array}{l}\text { Time } \\
\text { at this } \\
\text { stress }\end{array}$ & $\begin{array}{l}\text { Exten- } \\
\text { sion at } \\
\text { end of } \\
\text { test at } \\
\text { this } \\
\text { stress }\end{array}$ & $\begin{array}{l}\text { Mean } \\
\text { creep } \\
\text { rate at } \\
\text { this } \\
\text { stress }\end{array}$ & $\begin{array}{l}\text { Tim } \\
\text { at th } \\
\text { stres }\end{array}$ & \begin{tabular}{l|c} 
& Ex \\
ne & sio \\
his & en \\
ss & tes \\
& t \\
& st
\end{tabular} & $\begin{array}{l}\text { xten- } \\
\text { on at } \\
\text { ad of } \\
\text { st at } \\
\text { this } \\
\text { tress }\end{array}$ & $\begin{array}{c}\text { Mean } \\
\text { creep } \\
\text { rate at } \\
\text { this } \\
\text { stress }\end{array}$ & $\begin{array}{l}\text { Time } \\
\text { at this } \\
\text { stress }\end{array}$ & $\begin{array}{l}\text { Exten- } \\
\text { sion at } \\
\text { end of } \\
\text { test at } \\
\text { this } \\
\text { stress }\end{array}$ & $\begin{array}{c}\text { Total } \\
\text { time } \\
\text { of test }\end{array}$ & $\begin{array}{c}\text { Plastic } \\
\text { exten- } \\
\text { sion }\end{array}$ & $\begin{array}{l}\text { Reduc- } \\
\text { tion of } \\
\text { area }\end{array}$ & $\begin{array}{c}\log _{e} \\
\left(A_{0} / A_{f}\right)\end{array}$ & $\begin{array}{l}\text { True } \\
\text { stress }\end{array}$ & & & & \\
\hline$A-5 \ldots$ & $\begin{array}{c}\% / 1,000 \\
h r \\
0.78\end{array}$ & $\begin{array}{c}h r \\
2185.5\end{array}$ & $\begin{array}{c}\% \\
29.374\end{array}$ & $\begin{array}{c}\% / 1,000 \\
h r \\
1.1\end{array}$ & $\begin{array}{c}h r \\
2808\end{array}$ & 8.8 & $\% 2.578$ & $\begin{array}{r}\% / 1,000 \\
h r \\
58.5\end{array}$ & $\begin{array}{l}h r \\
383.5\end{array}$ & $\begin{array}{l}\% \\
55.0\end{array}$ & $\begin{array}{c}h r \\
19,200\end{array}$ & $\begin{array}{l}\% \\
55.0\end{array}$ & ${ }^{\%}{ }_{84}$ & 1.820 & $\begin{array}{l}l b / \text { in }^{2} \\
296,200\end{array}$ & \multirow{3}{*}{\multicolumn{4}{|c|}{ 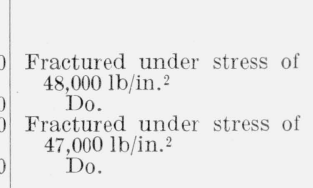 }} \\
\hline $\begin{array}{l}\mathrm{A}-9 \\
\mathrm{~A}-4 \ldots\end{array}$ & $\begin{array}{r}.41 \\
46.9\end{array}$ & $\begin{array}{r}2880.5 \\
526.3\end{array}$ & $\begin{array}{l}29.392 \\
59.5\end{array}$ & 2. 6 & 1367 & 7.3 & 32. 961 & 270 & 85.5 & 56.0 & $\begin{array}{l}20,000 \\
13,700\end{array}$ & $\begin{array}{l}56.0 \\
59.5\end{array}$ & $\begin{array}{l}85 \\
87\end{array}$ & $\begin{array}{l}1.913 \\
2.037\end{array}$ & $\begin{array}{l}325,200 \\
360,300\end{array}$ & & & & \\
\hline A-12. & 24.4 & 911.0 & 60.3 & & & & & & & & 14,500 & 60.3 & 85 & 1.894 & 312,100 & & & & \\
\hline
\end{tabular}

a The mean creep rate $(\% / 1,000 \mathrm{hr})$ is defined as that creep rate obtained by dividing the total plastic extension (percent) at the designated stress by the time $\mathrm{hr} / 1,000)$ at the designated stress. 
TABLE 2. Effect of rate of loading on creep of high-purity nickel, initially as annealed-Continued

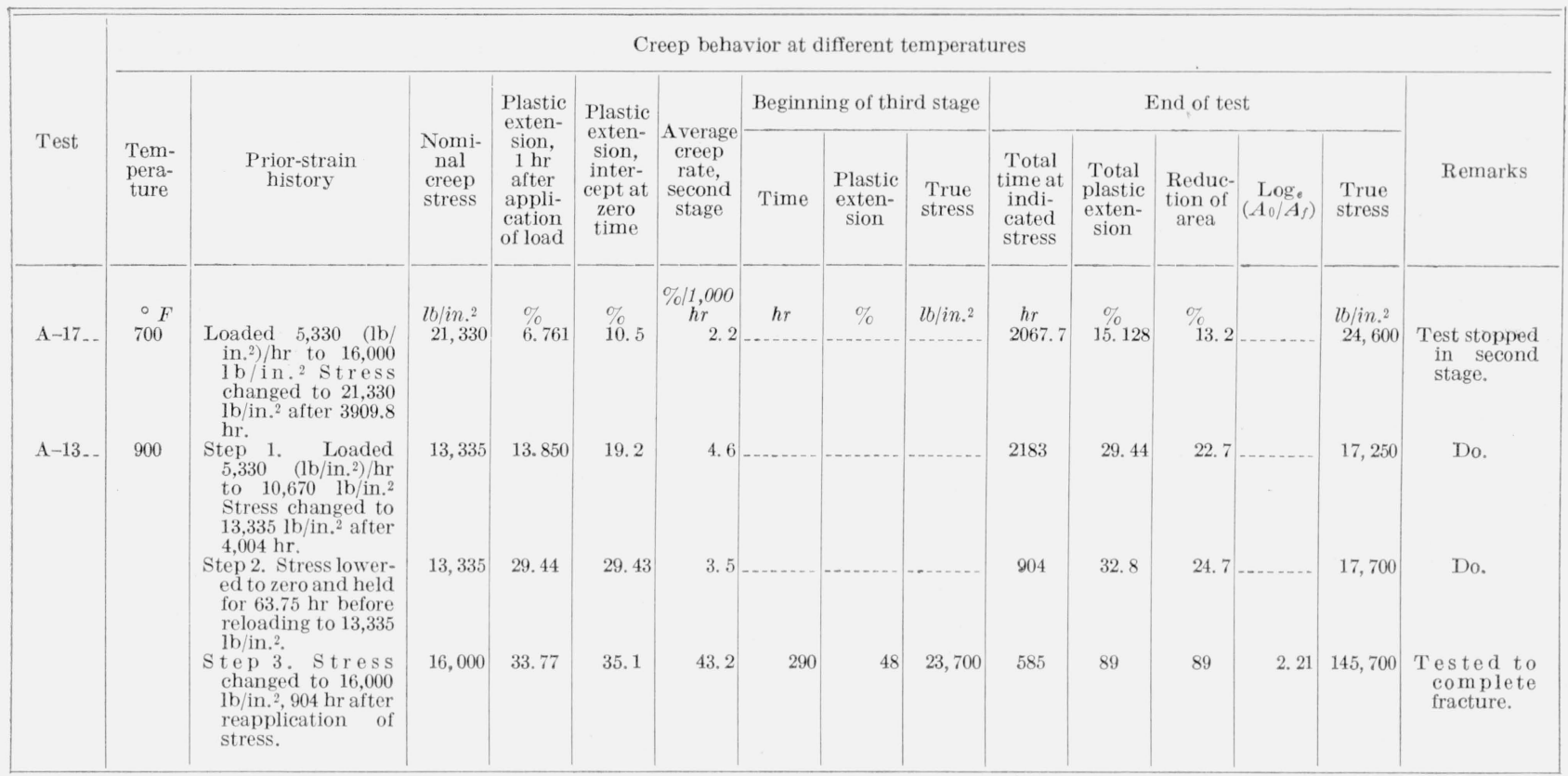

TABLE 3. Effect of prisr-strain history on the mechanical properties, at room temperature, of high-purity nickel, initially as annealed at $1,100^{\circ} \mathrm{F}$ for $16 \mathrm{hr}$ and at $1,000^{\circ} \mathrm{F}$ for $8 \mathrm{hr}$

\begin{tabular}{|c|c|c|c|c|c|c|c|c|c|c|c|c|c|c|c|}
\hline \multirow{3}{*}{ Specimen } & \multirow{3}{*}{$\begin{array}{l}\text { Additional thermal- } \\
\text { strain history }\end{array}$} & \multirow{3}{*}{$\begin{array}{l}\text { Yield } \\
\text { strength } \\
(0.2 \% \\
\text { offset })\end{array}$} & \multicolumn{5}{|c|}{ Maximum load a } & \multicolumn{2}{|c|}{$\begin{array}{l}\text { Beginning of } \\
\text { fracture a }\end{array}$} & \multicolumn{6}{|c|}{ Complete fracture } \\
\hline & & & \multirow{2}{*}{$\begin{array}{l}\text { T'ensile } \\
\text { strength }\end{array}$} & \multirow[b]{2}{*}{$\begin{array}{l}\text { True } \\
\text { stress }\end{array}$} & \multirow[b]{2}{*}{$\begin{array}{l}\text { Strain } \\
\text { in } 2 \text { in. }\end{array}$} & \multirow[b]{2}{*}{$\begin{array}{l}\text { Reduc- } \\
\text { tion } \\
\text { in } \\
\text { area }\end{array}$} & \multirow[b]{2}{*}{$\begin{array}{l}\text { True } \\
\text { strain }\end{array}$} & \multirow[b]{2}{*}{$\begin{array}{l}\text { True } \\
\text { stress }\end{array}$} & \multirow[b]{2}{*}{$\begin{array}{l}\text { True } \\
\text { strain }\end{array}$} & \multirow[b]{2}{*}{$\begin{array}{l}\text { True } \\
\text { stress }\end{array}$} & \multicolumn{2}{|c|}{$\begin{array}{l}\text { Elongation } \\
\text { in } 2 \text { in. }\end{array}$} & \multicolumn{2}{|c|}{$\begin{array}{l}\text { Reduction of } \\
\text { area }\end{array}$} & \multirow{2}{*}{$\begin{array}{c}\text { True } \\
\text { strain } \\
\text { (tensile } \\
\text { test } \\
\text { only) }\end{array}$} \\
\hline & & & & & & & & & & & $\begin{array}{c}\text { Tensile } \\
\text { test } \\
\text { only }\end{array}$ & $\begin{array}{l}\text { Creep } \\
\text { and } \\
\text { tensile } \\
\text { test }\end{array}$ & $\begin{array}{c}\text { Tensile } \\
\text { test } \\
\text { only }\end{array}$ & $\begin{array}{l}\text { Creep } \\
\text { and } \\
\text { tensile } \\
\text { test }\end{array}$ & \\
\hline $\mathrm{C}-9 \ldots$ & $\begin{array}{l}\text { Subjected to no addi- } \\
\text { tional treatment. }\end{array}$ & $\begin{array}{l}\text { lb/in. }{ }^{2} \\
12,500\end{array}$ & $\begin{array}{l}l b / \text { in }^{2} \\
51,600\end{array}$ & $\begin{array}{l}\text { lb/in. }{ }^{2} \\
72,300\end{array}$ & $41^{\%}$ & ${ }^{\%} 9^{\circ}$ & $\begin{array}{l}\log _{e} \\
\left(A_{0} A\right) \\
0.340\end{array}$ & $\begin{array}{c}l b / i n .^{2} \\
145,300\end{array}$ & $\begin{array}{l}\log _{\odot} \\
\left(A_{0} / A\right) \\
1.65\end{array}$ & $\begin{array}{l}\text { lb/in. }{ }^{2} \\
222,800\end{array}$ & 56 & $\%$ & 87 & $\%$ & $\begin{array}{l}\log _{e} \\
\left(A_{0} / A\right) \\
2.076\end{array}$ \\
\hline $\mathrm{E}-5 \ldots$ & $\begin{array}{l}\text { Tested in creep for } 1,036 \\
\text { hr at } 900^{\circ} \mathrm{F} \text { to a reduc- } \\
\text { tion of area of } 12 \text { per- } \\
\text { cent. }\end{array}$ & 21,700 & 53,400 & 75,500 & 40 & 28.5 & .336 & 151,300 & 1. 536 & 248,500 & 53 & 79 & 87 & 88.5 & 2. 032 \\
\hline $\mathrm{E}-4 \ldots$ & $\begin{array}{l}\text { Tested in creep for } 2,829 \\
\text { hr at } 900^{\circ} \mathrm{F} \text { to a reduc- } \\
\text { tion of area of } 19 \text { per- } \\
\text { cent. }\end{array}$ & 24,000 & 54,800 & 74,900 & 37 & $2 \pi$ & .314 & 144,600 & 1.485 & 226,000 & 49 & 91 & 85.5 & 88 & 1. 932 \\
\hline A-6 6 & $\begin{array}{l}\text { Tested in creep for } 1,870 \\
\text { hr at } 900^{\circ} \mathrm{F} \text { to a reduc- } \\
\text { tion of area of } 42.0 \text { per- } \\
\text { cent. }\end{array}$ & 39,800 & 63,100 & 82,900 & 31.5 & 24 & .273 & 139,700 & 1. 233 & 184,900 & 22 & 114 & 78 & 87 & 1. 514 \\
\hline $\mathrm{A}-19 \ldots$ & $\begin{array}{l}\text { Anncaled at } 1,750^{\circ} \mathrm{F} \text { for } \\
1 \mathrm{hr} \text {. }\end{array}$ & 6,300 & 47,100 & 66,900 & 42 & 29.5 & .351 & 122,400 & 1. 492 & 230,500 & 65 & & 88 & & 2.125 \\
\hline $631-\mathbf{A}_{\ldots} \ldots$ & $\begin{array}{l}\text { Cold-drawn } 30 \text { percent } \\
\text { reduction of area; fol- } \\
\text { lowed by annealing at } \\
1,750^{\circ} \mathrm{F} \text { for } 1 \mathrm{hr} \text {. }\end{array}$ & 6,700 & 50,700 & 71,000 & 40 & 28.5 & .337 & 124,800 & 1.353 & 217,200 & 63 & & 85 & & 1.907 \\
\hline$A-8 \ldots$ & $\begin{array}{l}\text { Tested in creep for } 2,138 \\
\text { hr at } 900^{\circ} \mathrm{F} \text { to a reduc- } \\
\text { tion of area of } 25.4 \text { per- } \\
\text { cent before annealing } \\
\text { at } 1,750^{\circ} \mathrm{F} \text { for } 1 \mathrm{hr} \text {. }\end{array}$ & 7,200 & 46,000 & 67,300 & 46.5 & 31.5 & .381 & 116.600 & 1. 469 & 169,400 & 64.5 & 104 & 84 & 88 & 1.843 \\
\hline$A-17 \ldots$ & $\begin{array}{l}\text { Tested in creep for } 5,978 \\
\text { hr at } 700^{\circ} \mathrm{F} \text { to a reduc- } \\
\text { tion of area of } 30.8 \text { per- } \\
\text { cent hefore annealing } \\
\text { at } 1,750^{\circ} \mathrm{F} \text { for } 1 \mathrm{hr} \text {. }\end{array}$ & 3,500 & 44,700 & 70,400 & 57.5 & 36.5 & .453 & 117,400 & 1. 616 & 193,700 & 67 & 118 & 88 & 92 & 2.117 \\
\hline
\end{tabular}

s The strain, reduction of area, or true-strain values at maximum load or at beginning of fracture are based on measurements obtained in the tensile tests. 
Tensile tests at room temperature were also made on specimens prepared from bar $\mathrm{A}$ and on two additional 7/8-in. round bars, designated $\mathrm{C}$ and $631-\mathrm{A}$ (table 3). A subsequent annealing treatment was carried out at $1,750^{\circ} \mathrm{F}$ on certain specimens prepared from bars $\mathrm{A}$ and $631-\mathrm{A}$ in order to produce a relatively coarse grain size (approximately 1.5- to 2-mm avg diam).

The preparation of the specimens and the apparatus used for creep testing have been previously described [1]. The creep specimens had a reduced section of 0.505 -in. diameter and a gage length of 2 in. Each specimen was heated in air to the desired temperature in an electrically heated furnace regulated by a photoelectric-type control. Each specimen was held at the temperature for $48 \mathrm{hr}$ before applying the loads. Increments of load were added at 1-hr intervals until the desired creep stress was reached. The load increment corresponded to a stress of $5,333 \mathrm{lb} /$ in. $^{2}$ unless the creep stress was not a multiple of 5,333. In that case, the final increment was smaller. This loading procedure (selected as standard) was modified in those tests designed to show the influence of rate of loading on creep behavior. All of the creep tests were made under constant loads and the creep-stress values (also designated as nominal stresses) were obtained by dividing the loads by the original cross-sectional area of the specimens.

The tensile tests at room temperature were made at a strain rate of approximately 1-percent reduction of area per minute. Usual recommended procedures were used for preparing specimens and making the Rockwell hardness measurements and in the preparation of specimens, by mechanical methods, for metallographic examination [3].

\section{Results and Discussion}

\subsection{Effect of Stress and Temperature on Creep Behavior}

The results of the creep tests made on specimens loaded at the standard rate are summarized in table 1 and shown in figures 1 to 15 .

\section{a. Resistance to Plastic Deformation}

The resistance of the nickel to plastic deformation decreased as the test temperatures were increased (fig. 1,A). Some idea of the reproducibility of the strain measurements $1 \mathrm{hr}$ after the application of stress increments of $5,330 \mathrm{lb} / \mathrm{in}^{2}{ }^{2}$ can be obtained from the lengths of the horizontal bars representing the range of extension values for the number of test specimens designated above these bars. The resistance to flow at each temperature was similar for all the nickel specimens tested at that selected temperature. Furthermore, no marked differences were obtained in the extension measurements made on the extensometer strips located $180^{\circ}$ apart on the specimen. (positions $\mathrm{x}$ and $\mathrm{y}$, respectively, fig. 1, B). This fact indicates that nearly axial loading was attained and accurate measurements of extension were made even in the primary stage of creep.

\section{b. Extension-Time Curves}

The families of curves in figures 2,3 , and 4 depict the creep behavior of the nickel in relation to different stress levels at temperatures of $700^{\circ}, 900^{\circ}$, and $1,200^{\circ} \mathrm{F}$, respectively. The extension-time curves for specimens tested at $300^{\circ} \mathrm{F}$ are given in figure 17 and will be discussed later. An attempt was made to select the applied loads so that at least one specimen in each series would be subject to the same load at each of the four temperatures used. However, this was impractical because of the wide differences in resistance to flow over the temperature range $300^{\circ}$ to $1,200^{\circ} \mathrm{F}$. For example, a specimen stressed at $9,330 \mathrm{lb} / \mathrm{in}^{2}$ at $1,200^{\circ} \mathrm{F}$ (fig. 4) fractured in $32.3 \mathrm{hr}$ at an extension of 91 percent, whereas a specimen stressed at $16,000 \mathrm{lb} / \mathrm{in}^{2}{ }^{2}$ at $700^{\circ} \mathrm{F}$ (fig. 2) lengthened only 5 percent in $3,900 \mathrm{hr}$. The appearance of the extension-time curves, as plotted, indicates that creep occurred in a continuous manner in all specimens except the one stressed at $4,010 \mathrm{lb} /$ in. $^{2}$ at $1,200^{\circ}$ F (fig. 4). The irregularity in the latter curve is believed to be due to a combination of strain hardening and recrystallization with recrystallization predominating; high-purity nickel recrystallizes at approximately $1,100^{\circ} \mathrm{F}$ [8]. However, when the data were plotted on a more expanded scale (not shown), irregularities in the extension-time curves were observed in each of the three stages of creep in all of the specimens tested to complete fracture. The presence of irregularities is clearly illustrated in the logarithm of creep rate-extension curves of figures 5 and 6 . The serrations in these curves are in excess of those that can be attributed to variations in test conditions. The magnitude of the serrations at low stresses appears to be greater than at the high-stress levels at equal temperatures, due, in part, to the use of the semilog relationship. The serrated curves, in general, may be considered as due to a repetitive series of reactions occurring consecutively, each with a different energy of activation as affected by the instantaneous condition of the nickel. These irregularities in the three stages of creep are considered, at least in part, to be due to such factors as grain orientations, grain rotation, formation of subgrains within the parent grains, strain hardening, recovery, and formation of cracks.

The shape of the curves for specimens tested at $300^{\circ} \mathrm{F}$ at stresses of 45,000 and $45,500 \mathrm{lb} / \mathrm{in}^{2}$ (fig. 5) $^{2}$ may be interpreted as indicating flow by the perdominance of the exhaustion mechanism of dislocations [10] and also the existence of a stress region between 45,500 and $46,000 \mathrm{lb} / \mathrm{in}^{2}{ }^{2}$ where the flow is predominately by the generation of dislocations. The considerable jaggedness shown in the curves for the specimens tested at $700^{\circ} \mathrm{F}$ were possibly accentuated by the nearness to the magnetic transformation (Curie point) of nickel $\left(680^{\circ} \mathrm{F}\right)$ [8].

Discontinuities obtained in some of the tensile properties of this high-purity nickel at both $300^{\circ}$ and $700^{\circ} \mathrm{F}$ were also discussed in a previous publication [3]. According to Köster [9], the elastic modulus in tension of nickel decreases as the test temperature is increased from $80^{\circ}$ to about $350^{\circ} \mathrm{F}$ 

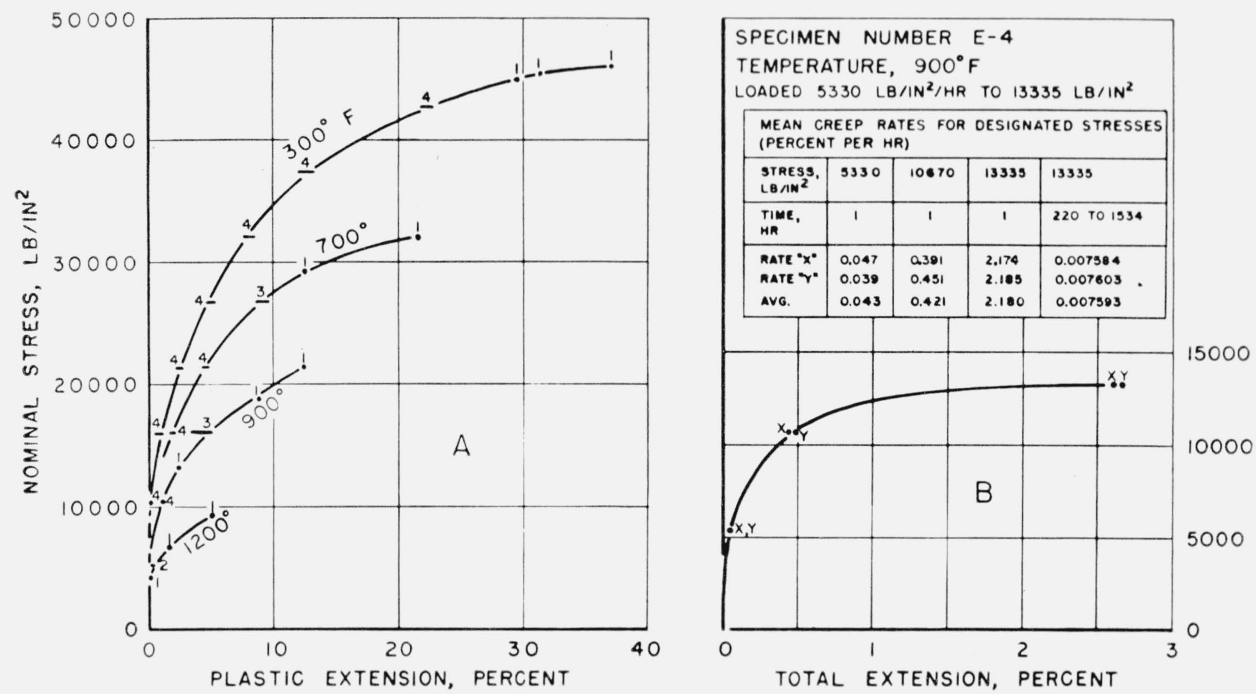

FIGURE 1. Effect of temperature on the stress-extension relation during loading of the annealed nickel.

The values for extension are those obtained after the application of the loads for a period of $1 \mathrm{hr}$.

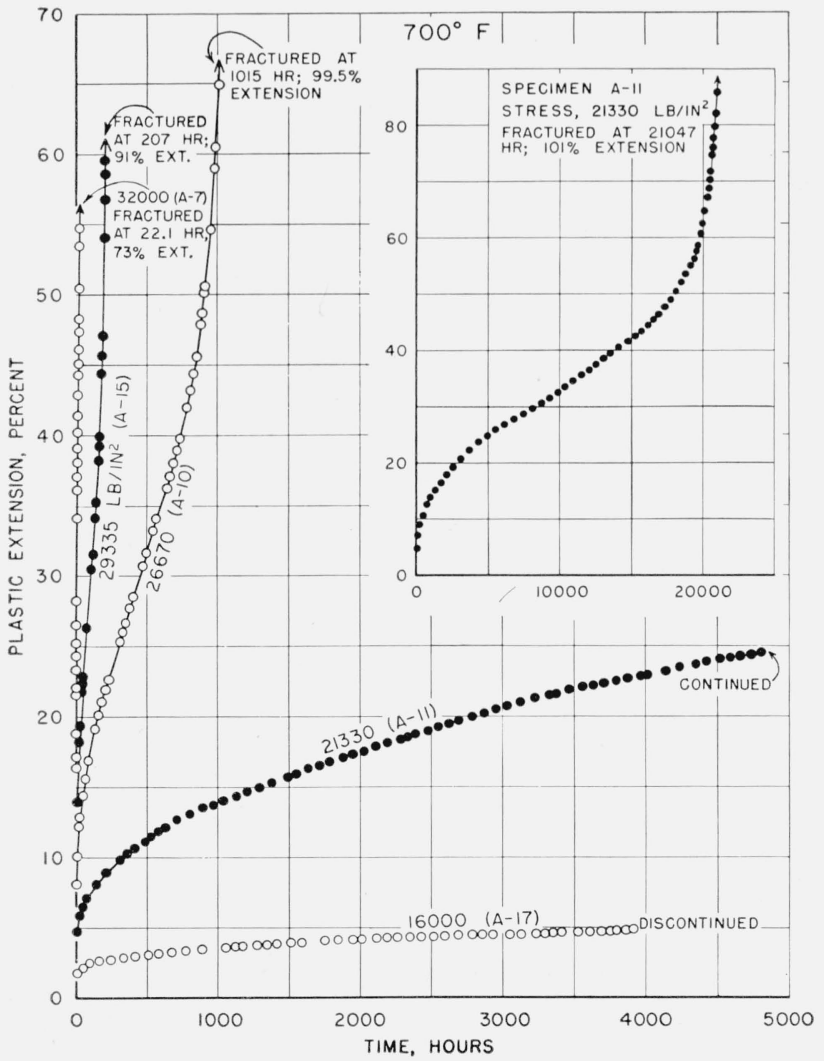

Figure 2. Extension-time curves for the nickel at $700^{\circ} \mathrm{F}$.

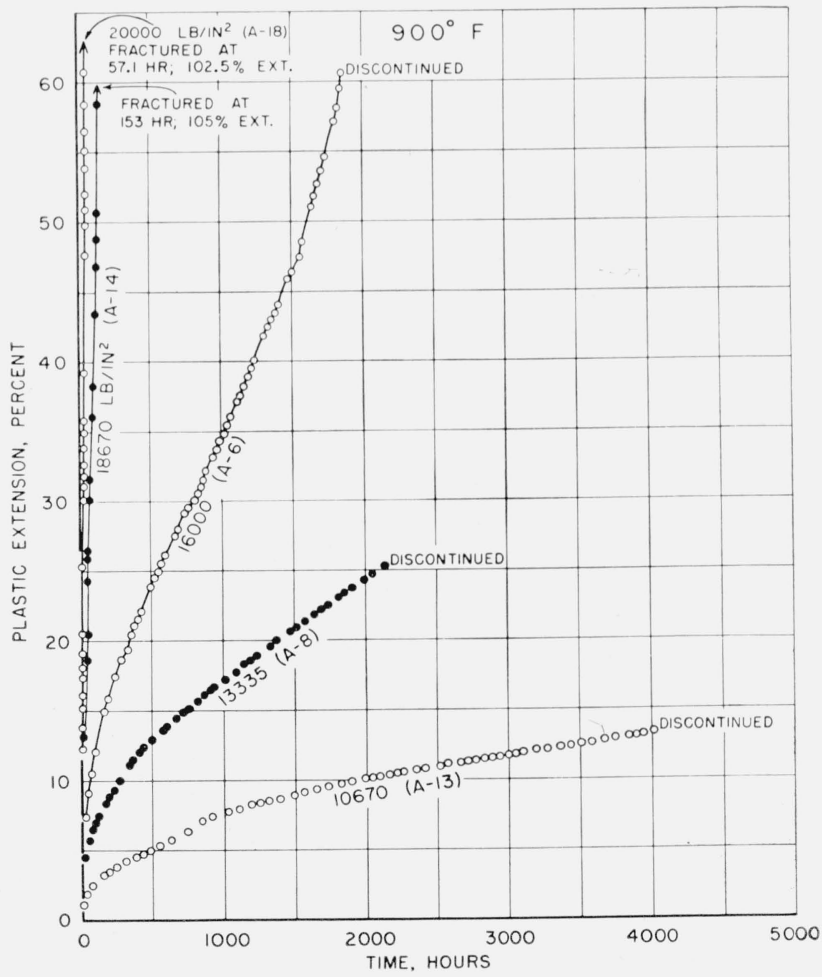

FiguRE 3. Extension-time curves for the nickel at $900^{\circ} \mathrm{F}$. 


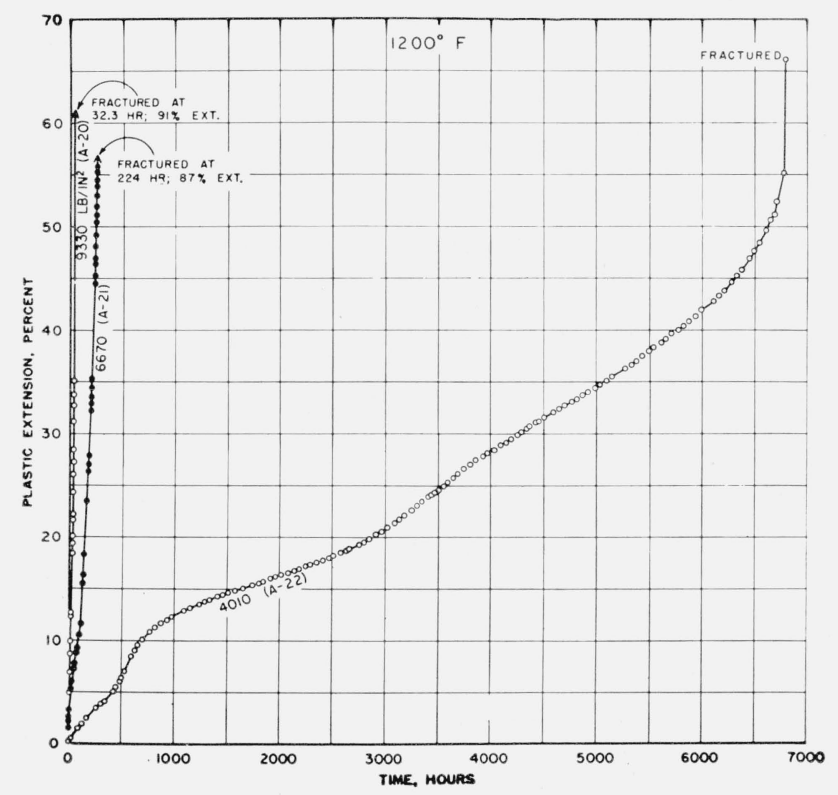

Figure 4. Extension-time curves for the nickel at $1,200^{\circ} \mathrm{F}$.
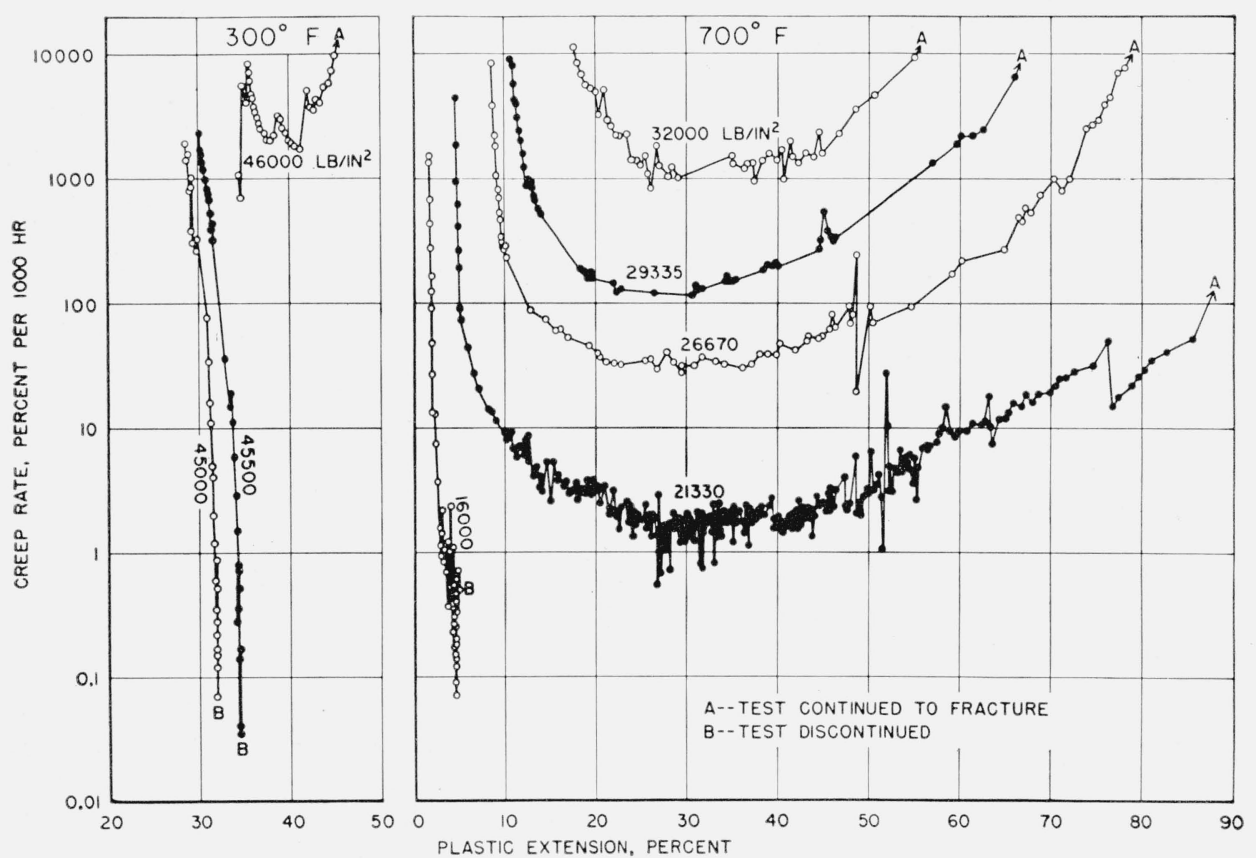

FiguRe 5. Relation of creep rate to plastic extension at $300^{\circ}$ and $700^{\circ} \mathrm{F}$.

334 

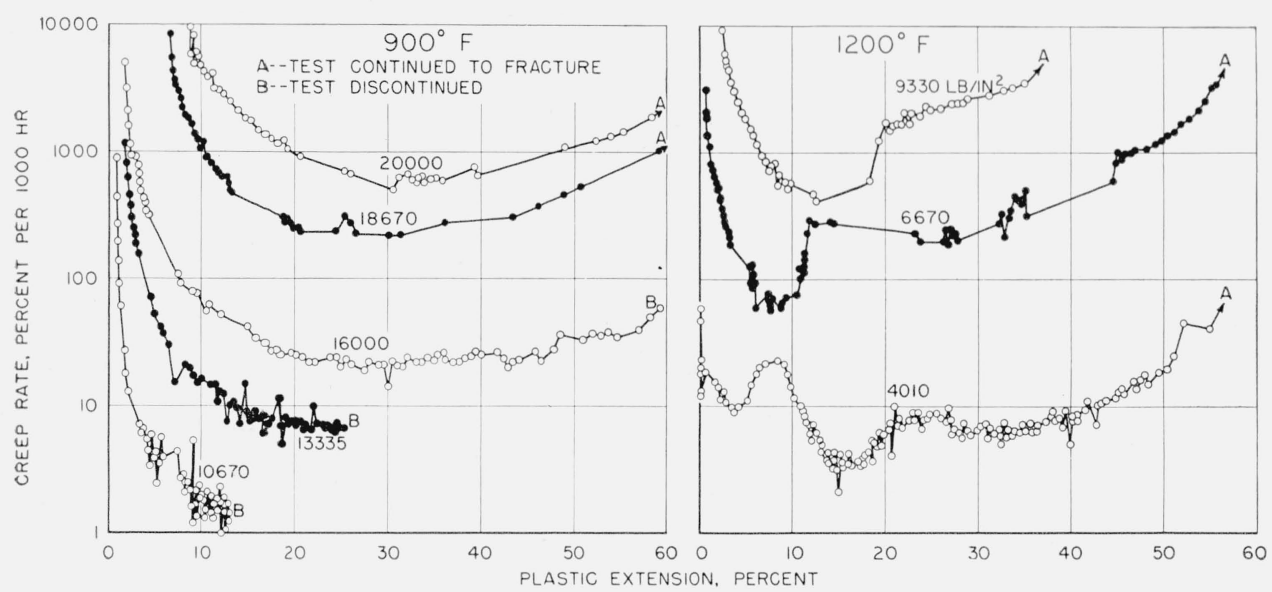

Figure 6. Relation of creep rate to plastic extension at $900^{\circ}$ and $1,200^{\circ} \mathrm{F}$.
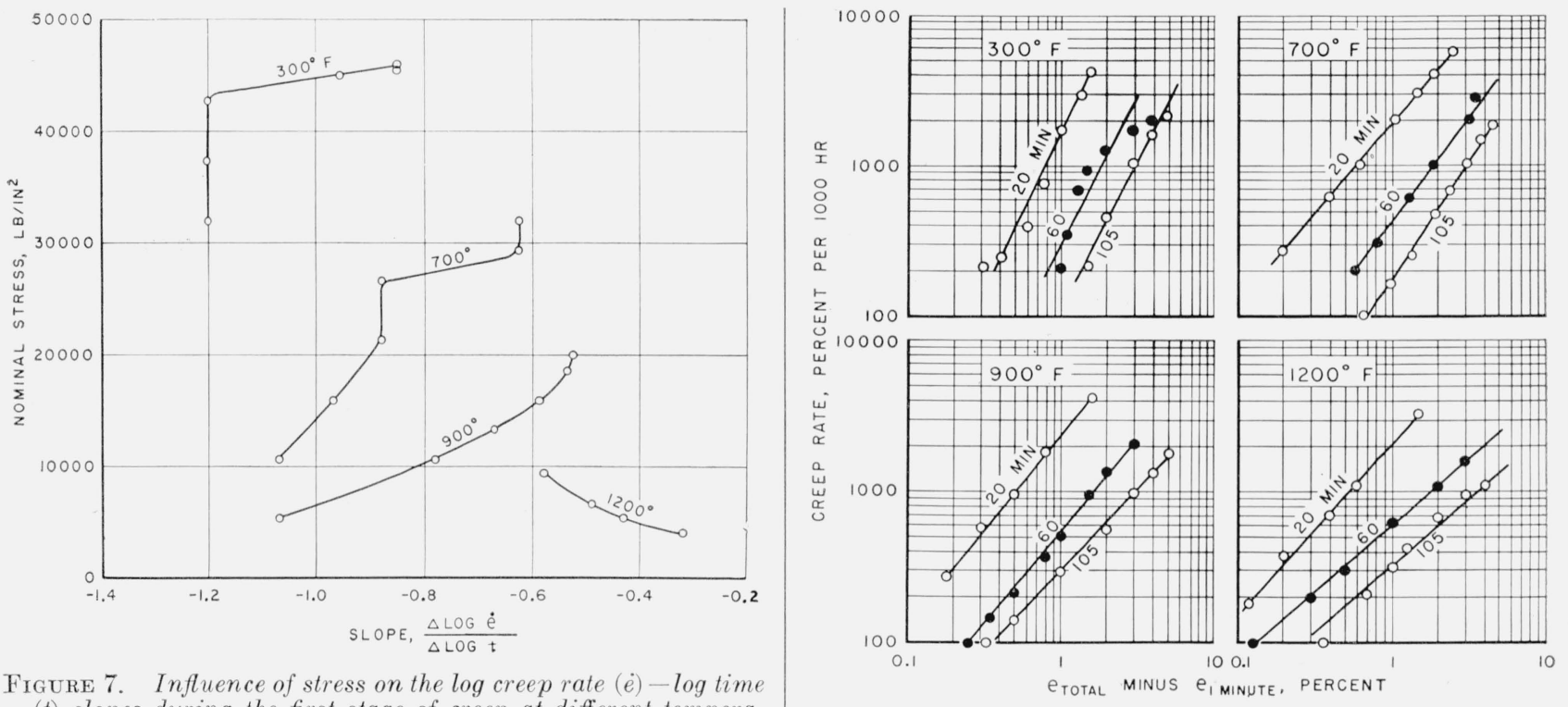

Figure 7. Influence of stress on the log creep rate $(\dot{e})-\log$ time ( $t$ ) slopes during the first stage of creep at different temperatures.

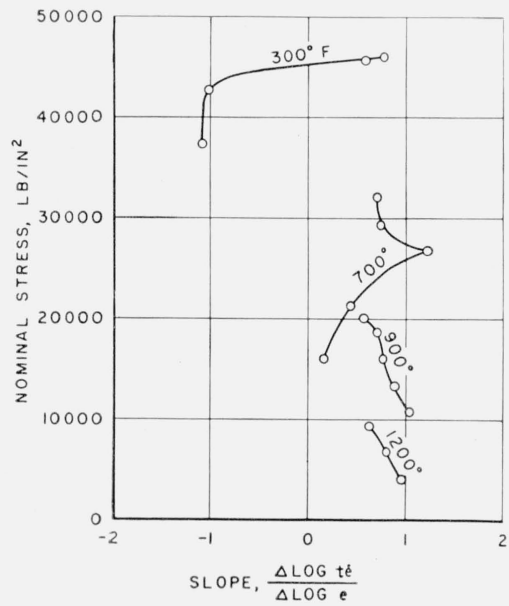

FIGURE 8. Influence of stress on the log product of time $(t)$ and creep rate $(\dot{e})-\log$ extension (e) slopes during the first stage of creep at different temperatures.

FIGURE 9. Relation of creep rate to plastic extension at different temperatures and times.

$e_{\text {total }}=$ extension at designated time; $e_{1 \mathrm{~min}}=$ extension at the end of $1 \mathrm{~min}$.

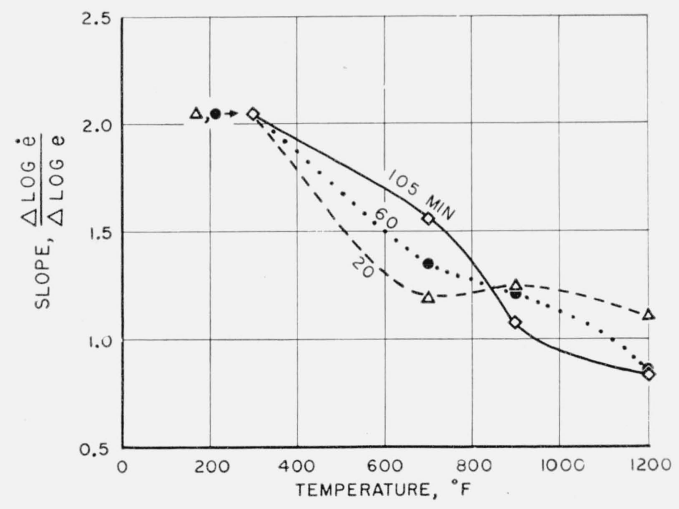

FiguRE 10. Variation in slope of log creep rate $(\dot{e})$ - log extension (e) curves of nickel with temperature at different times. 


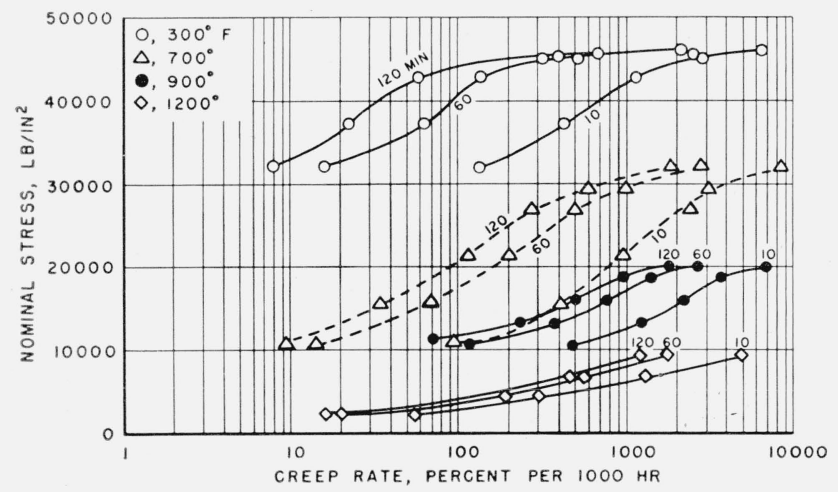

Figure 11. Relation of nominal stress:to first stage creep rate at different temperatures and times.

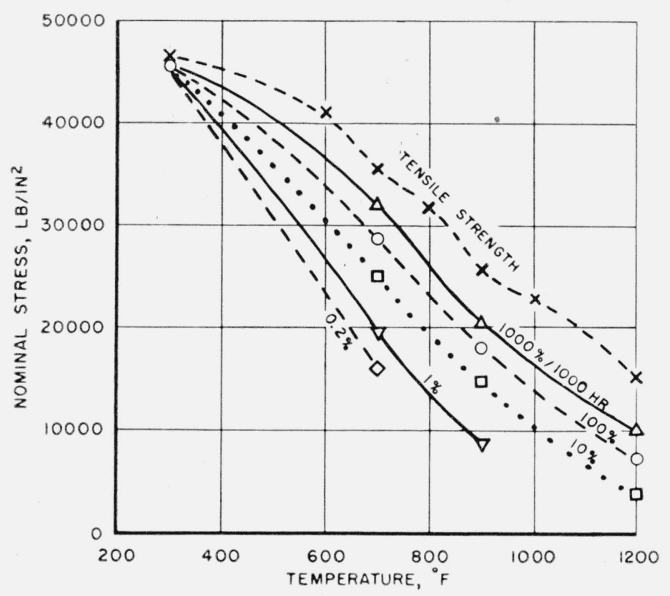

Figure 13. Variation in stress required to produce different creep rates in the second stage at different temperatures.

The influence of temperature on the tensile strength of the nickel is also shown.

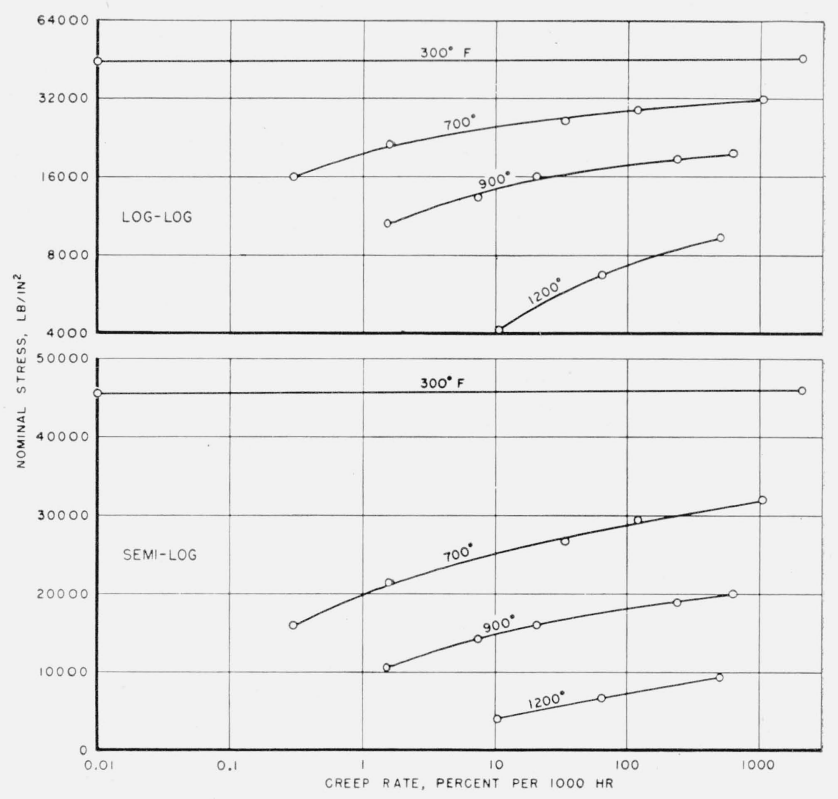

FIGURE 12. Influence of stress on the average creep rate during the second stage of creep at different temperatures.

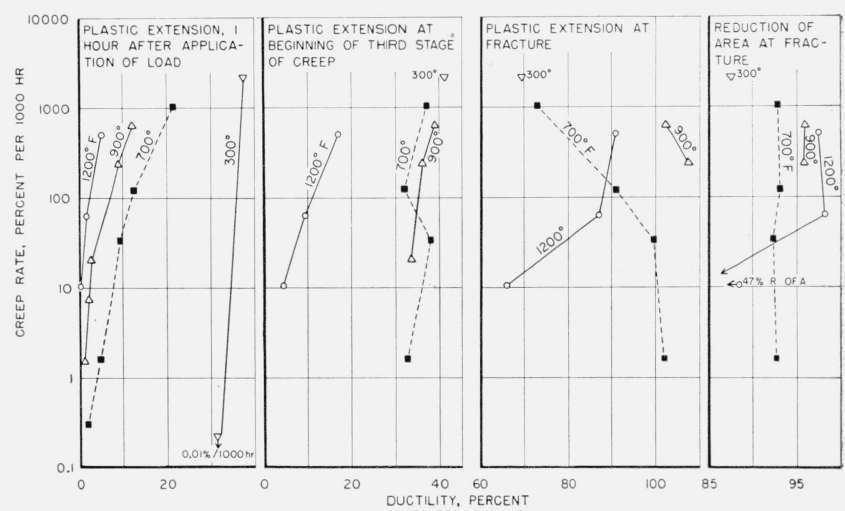

Figure 14. Relation of creep rate in the second stage to ductility at various stages of the creep tests.

FigurE 15. True stress-true strain relations at different temperatures and second stage creep rates.

$A_{0}$ and $A$ are initial and current cross-sectional areas, respectively, of the creep specimens. 
and it then increases with further increase in temperature to the Curie point $\left(680^{\circ} \mathrm{F}\right)$. The values at $80^{\circ}$ and $680^{\circ} \mathrm{F}$ were nearly the same. The modulus then decreases continuously as the temperature is increased from $680^{\circ}$ to $1,400^{\circ} \mathrm{F}$.

The discontinuities appear to increase in magnitude with decrease in stress both at $700^{\circ}$ and at $900^{\circ} \mathrm{F}$ (fig. 6 ). The latter temperature seems to be more favorable for a continuing balance between strain hardening and recovery. The curves for specimens tested at $1,200^{\circ} \mathrm{F}$ are representative of the effect of stress, in the recrystallization region, on the initiation of strain hardening of the original grains, followed by continuous recovery, then recrystallization, followed by grain growth and creep in the larger grains. These processes are sensitive to stress and temperature, as shown by the magnitude and the distribution of the discontinuities.

\section{c. First Stage of Creep}

The relationship between the logarithm of creep rate and the logarithm of time is nearly linear in the initial portion of the first stage of creep of the nickel specimens (curves are not shown). The cycling effects observed, however, are considered as indicating that the deformation process should be both stress and temperature dependent. In contrast, the analysis made by Andrade [11] indicated that the mechanism of deformation in the initial stage of creep is independent of stress, temperature, and chemical composition.

The effect of stress and temperature on the slope of the logarithmic creep-rate-time curves is shown in figure $7 .^{2}$ At $300^{\circ} \mathrm{F}$, the slopes are independent of stresses within the range of 32,000 to 43,000 $\mathrm{lb} / \mathrm{in}^{2}$, but the slope increases as the stress is further increased to $45,000 \mathrm{lb} / \mathrm{in}^{2}$ At $700^{\circ} \mathrm{F}$, the slope is independent of stress over some stress ranges, but it is strongly stress dependent over other ranges. At $900^{\circ} \mathrm{F}$, the slope shows a continuous increase with increase in creep stress; it appears to approach a limiting value at relatively high stress levels. Contrary to the trend at $900^{\circ} \mathrm{F}$, the slope of the curves for the specimens tested at $1,200^{\circ} \mathrm{F}$ shows a continuous decrease with increase in stress.

The present data were evaluated to ascertain the conformity of the creep of nickel to the exhaustion theory proposed by Mott and Nabarro [10] and modified by Davis and Thompson [12]. The exhaustion theory is considered as generally applicable to the primary creep of metals at relatively low temperatures and stresses. The modified theory predicts a linear relation between the logarithm of the product of the creep rate and time and the logarithm of the strain; in this plot, the values for the slope of the curves should be within the range of $-1 / 2$ and +1 . Most of the experimental results (fig. 8) agree closely with the results predicted by the modified theory.

The relation of creep rate to strain for periods of 20,60 , and $105 \mathrm{~min}$ after the application of the creep stresses at different temperatures is illustrated by

2 The increments, such as $\Delta \log t$ or $\Delta \log \dot{e}$, in this and other diagrams were taken sufficiently large so as to eliminate the effects of the small oscillations of creep rate. the results summarized in figure 9. The maximum deviation from linearity (log-log plot) is shown in the experimental results obtained $60 \mathrm{~min}$ after the application of the stresses at $300^{\circ} \mathrm{F}$; this temperature is within the range where strain aging can occur in the nickel. Some deviations from linearity are also shown in the values for a period of $105 \mathrm{~min}$ at $1,200^{\circ}$ $\mathrm{F}$; recrystallization can occur at this temperature. The slopes of the family of curves shown for specimens at $300^{\circ} \mathrm{F}$ were nearly constant (see also fig. 10), whereas the slopes varied somewhat with the other test temperatures used. The slopes of the three curves again coincide at a temperature of approximately $850^{\circ} \mathrm{F}$.

The influence of stress on the creep rate for selected periods of 10,60 , and $120 \mathrm{~min}$ after the application of stress at the different test temperatures is shown in the results of figure 11. The contour of the family of sigmoidal curves (semilog plot) is affected by both time and temperature; the curves representing the values, as plotted on a log-log basis (not shown) are also sigmoidal. The curves (fig. 11) also indicate that, at each temperature used, there is a threshold stress below which no measurable creep would occur.

\section{d. Second and Third Stages of Creep}

Numerous theories have been proposed to explain the effects of stress on the rate of creep in the second stage. Linear relations have been obtained between stress and creep rate of various metallic materials when the experimental values were plotted on the basis of $\log -\log$, semilog, or creep rate hyperbolic sine function of stress.

The influence of stress on the secondary creep rate of the nickel at different temperatures is shown by the results given in figure 12 . The relationship between stress and creep rate, in general, is not linear when the experimental values for the nickel are plotted on either a $\log -\log$ or a semilog basis; a linear relation is obtained in the semilog plot of the values obtained for the specimens at $1,200^{\circ} \mathrm{F}$. The resistance to creep increased with a decrease in test temperature. At $300^{\circ} \mathrm{F}$ the initially annealed nickel had a high resistance to creep for stresses up to $45,500 \mathrm{lb} / \mathrm{in}^{2}$, but with a further increase in stress of $500 \mathrm{lb} /$ in. $^{2}$ the creep rate increased by a factor of about 100,000 . It is noteworthy that these stresses used in the creep tests are only about 1,500 and $1,000 \mathrm{lb} / \mathrm{in}^{2}{ }^{2}$, respectively, below the tensile strength of the nickel at $300^{\circ} \mathrm{F}$ (fig. 13). The high resistance of the nickel to creep at $300^{\circ} \mathrm{F}$ is attributed to a combination of strain and age hardening and relatively low rate of recovery. At $700^{\circ}, 900^{\circ}, 1,200^{\circ} \mathrm{F}$ (fig. 12), the creep rates increased continuously with an increase in stress in the ranges investigated. This curvilinear relationship indicates that the deformation characteristic (strain hardening and recovery) of the nickel continuously changed as the stress was increased. However, the linear relationship obtained between the stress and $\log$ creep rate of the values for specimens tested at $1,200^{\circ} \mathrm{F}$ is indicative of an approach to viscous flow at this temperature.

The relation between stress and temperature to produce various second-stage creep rates is shown in 
figure 13. The trend is for the curves to converge at a test temperature of about $300^{\circ} \mathrm{F}$. The magnitude of differences between the curves corresponding to the various creep rates emphasizes the importance of a knowledge of the engineering properties of a metallic material and the accompanying microstructures in the design of components for use at elevated temperatures.

The relation between second-stage creep rate and ductility is shown in figure 14 . The amount of plastic extension on loading decreased continuously with increase in temperature necessary to produce equivalent second-stage creep rates.

Relatively little information is available in the literature on the third stage of creep. The initiation of this stage has been attributed to such factors as the beginning of microcracking, increase in creep stress due to a decrease in the area of the specimen, atomic rearrangement, etc.

The plastic extension at the beginning of the third stage of creep increased with increase in secondary creep rate at both $900^{\circ}$ and $1,200^{\circ} \mathrm{F}$ (fig. 14). Although the change in ductility with creep rate was more pronounced at the higher temperature, the amount of plactic extension at the beginning of the third stage was appreciably greater at $900^{\circ}$ than at $1,200^{\circ} \mathrm{F}$. At $700^{\circ} \mathrm{F}$, however, the extension-creep rate curve shows reversals in the intermediate range of rates. Only one specimen was tested into the third stage and to complete fracture at $300^{\circ} \mathrm{F}$. A maximum value for plastic extension at the beginning of the third stage was attained with this specimen, but its extension at fracture was appreciably less than that of some other specimens fractured at $700^{\circ}, 900^{\circ}$, or $1,200^{\circ} \mathrm{F}$. All the fractured specimens had an extension of 65 percent or more before fracturing; in some cases, the elongation in 2 in. exceeded 100 percent. However, the effect of secondary creep rate on the plastic extension at fracture varied with the test temperatures used. At $700^{\circ}$ and $900^{\circ} \mathrm{F}$, the extension increased as the creep rates were decreased, whereas at $1,200^{\circ} \mathrm{F}$ the extension increased with increase in the rates. The reduction of area at fracture was nearly insensitive to the rate of extension used, but the general trend was for the reduction of area to increase with an increase in temperature; however, one specimen tested at a secondary creep rate of about 10 percent per $1,000 \mathrm{hr}$ at $1,200^{\circ} \mathrm{F}$ had a relatively low value for the reduction of area $(47 \%)$.

The true strain, $\log _{\mathrm{e}}\left(A_{0} / A\right)$, at the beginning of the third stage of creep increased continuously with the true stress at $900^{\circ}$ and $1,200^{\circ} \mathrm{F}$ (fig. 15), but reversals were again obtained in the curve representing the true-stress-true-strain relation at $700^{\circ} \mathrm{F}$. At each of these temperatures, the true stress (see table 1) increased continuously with increase in the creep rate in the second stage. The true-strain values at the beginning of the third stage were appreciably higher in all of the specimens tested at $300^{\circ}, 700^{\circ}$, and $900^{\circ} \mathrm{F}$ than in the specimens tested at $1,200^{\circ} \mathrm{F}$, even though the creep rate of some of the former specimens was slower than those at $1,200^{\circ} \mathrm{F}$. Thus, the phenomenon of recrystallization that

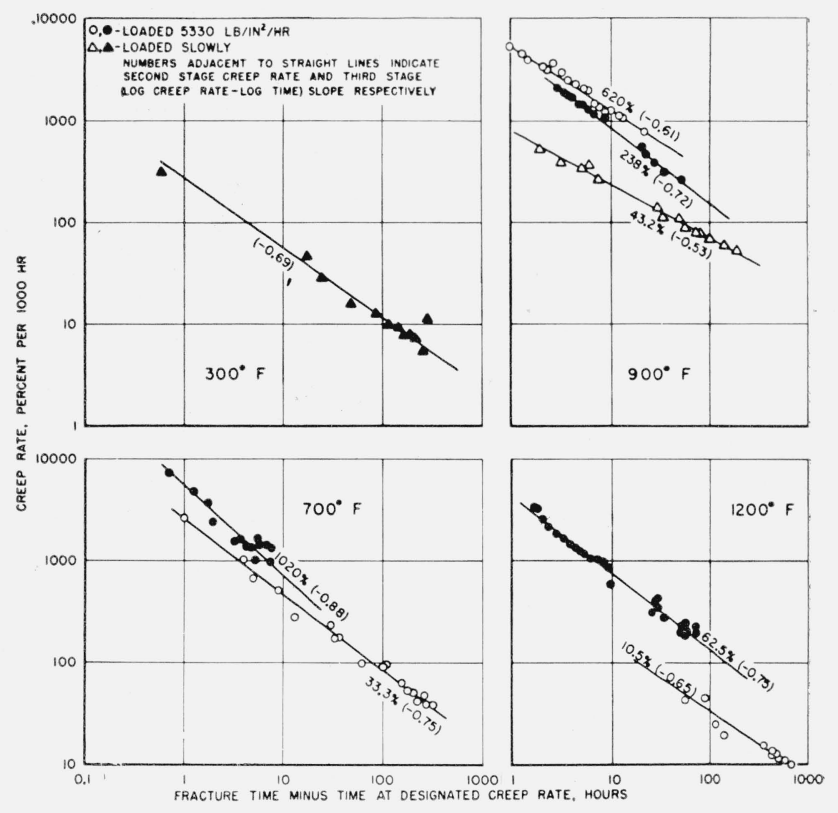

FIGURE 16. Effects of temperature, second stage creep rote, and rate of loading on the creep rate-time relation in the third stage of creep.

Data at $300^{\circ} \mathrm{F}$ was obtained for specimen A-5 under ereep stress of $48,000 \mathrm{lb} / \mathrm{in}$. (see table 2 for rate of loading).

occurred at $1,200^{\circ} \mathrm{F}$ was not accompanied by an increase in ductility as measured by the true strain at the beginning of the third stage.

The true strain at fracture was relatively insensitive to variations in true stress at $700^{\circ}$ or $900^{\circ} \mathrm{F}$, whereas at $1,200^{\circ} \mathrm{F}$ the true strain was materially affected by changes in true stress or secondary creep rate. Except for one specimen tested at a slow rate, the true strain at fracture increased with an increase in test temperature.

The effect of temperature and secondary creep rate on the rate-time relation during the third stage of creep is shown in figure 16 . The slope of the linear curves differed somewhat as the test conditions were altered. The general trend was for the numerical values of slopes of these curves to be steeper for the specimens tested at $700^{\circ}$ or $1,200^{\circ} \mathrm{F}$ than those at $900^{\circ} \mathrm{F}$.

An analysis of measurements of ductility made under creep conditions showed that the flow characteristics of the nickel cannot always be predicted accurately from results based solely on determinations of stress, time, and ductility at fracture.

\subsection{Effect of Rate of Loading on Creep Behavior}

Tests were made at $300^{\circ}, 700^{\circ}$, and $900^{\circ} \mathrm{F}$ to determine the influence of rate of loading to different stress levels on the creep characteristic of the nickel initially as annealed. The test conditions and results are summarized in table 2 and figures 17 to 24 .

Extension-time curves are given in figure 17 for specimens tested at $300^{\circ} \mathrm{F}$ that were loaded at the standard rate until the creep stresses of 37,330 , 

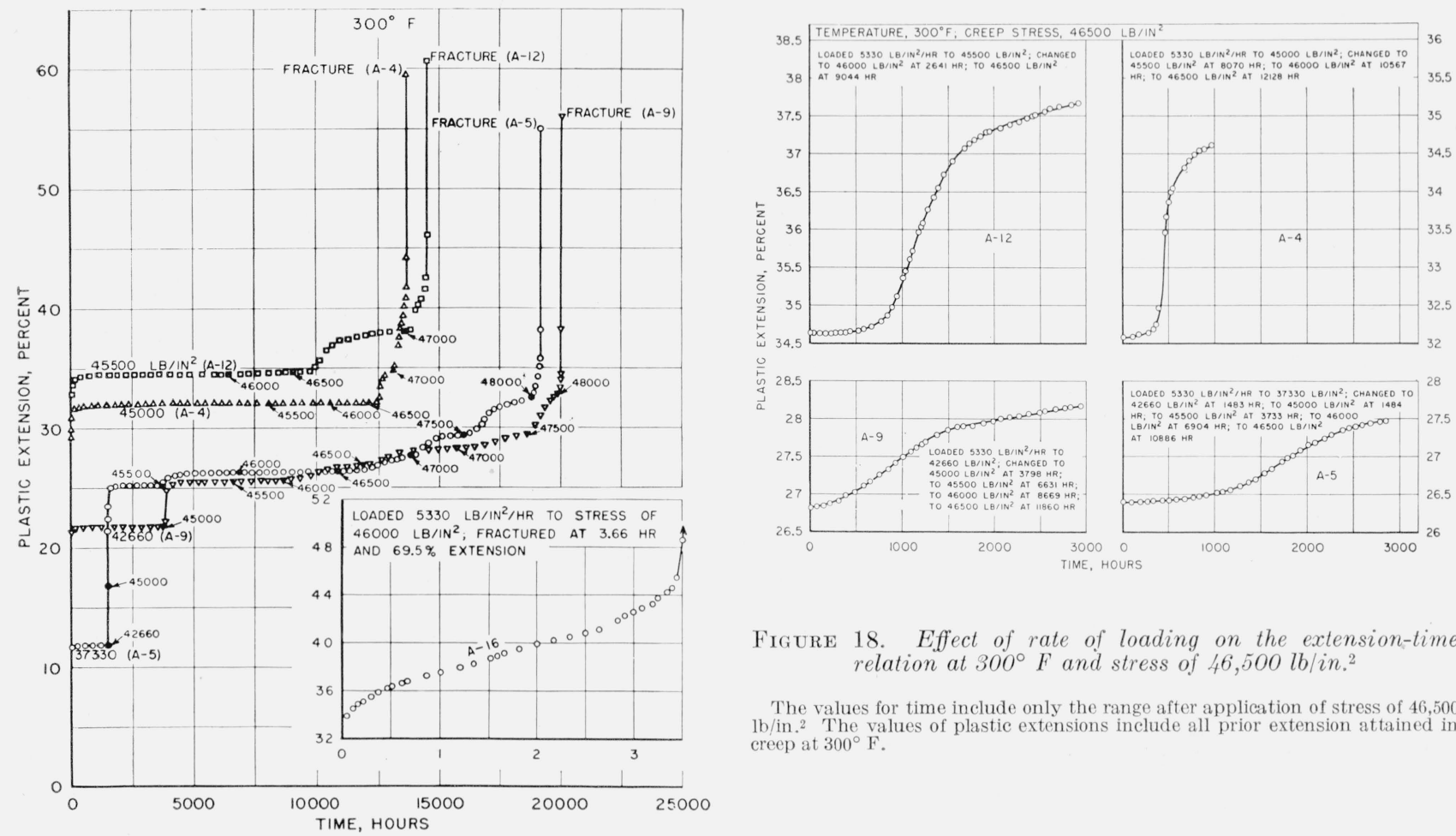

FIGURE 18. Effect of rate of loading on the extension-time relation at $300^{\circ} \mathrm{F}$ and stress of $46,500 \mathrm{lb} / \mathrm{in} .{ }^{2}$

The values for time include only the range after application of stress of 46,500 $\mathrm{lb} / \mathrm{in}^{2}$ The values of plastic extensions include all prior extension attained in creep at $300^{\circ} \mathrm{F}$.

Figure 17. Extension-time curves for specimens loaded at different rates to different stresses at $300^{\circ} \mathrm{F}$.

Solid symbols indicate points where stress was changed.

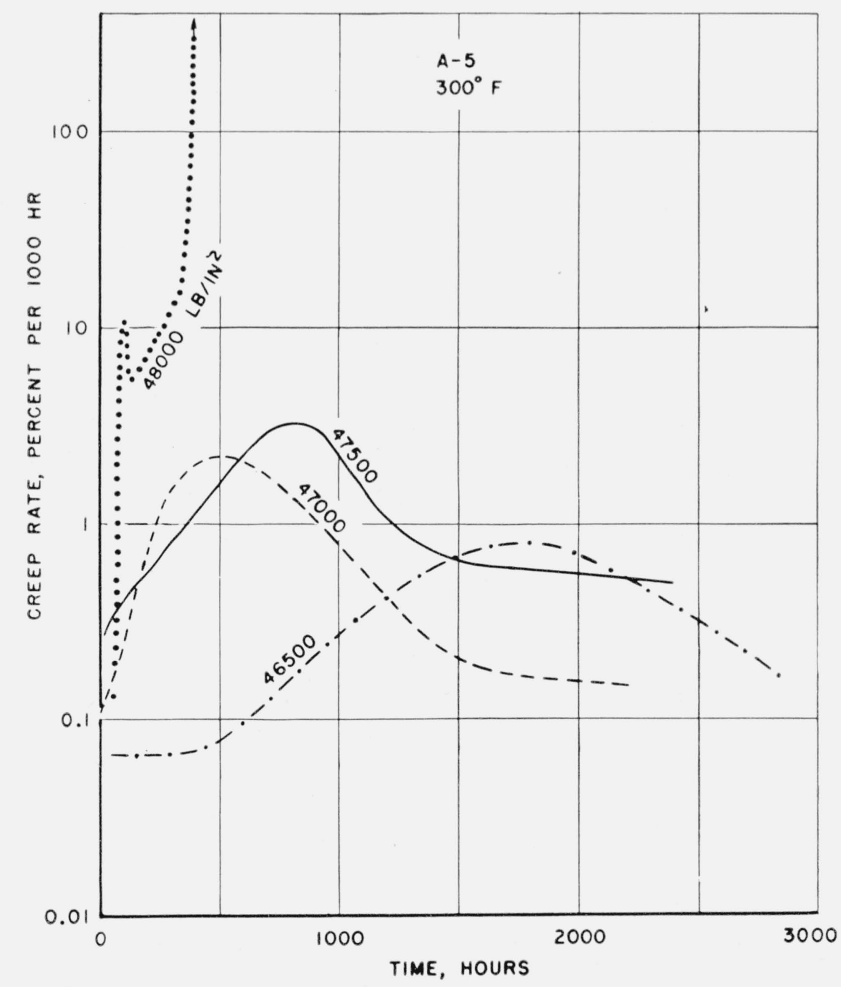

Figure 19. Creep rate-time relation of a specimen tested at $300^{\circ} F$ and with increasing stress levels. 


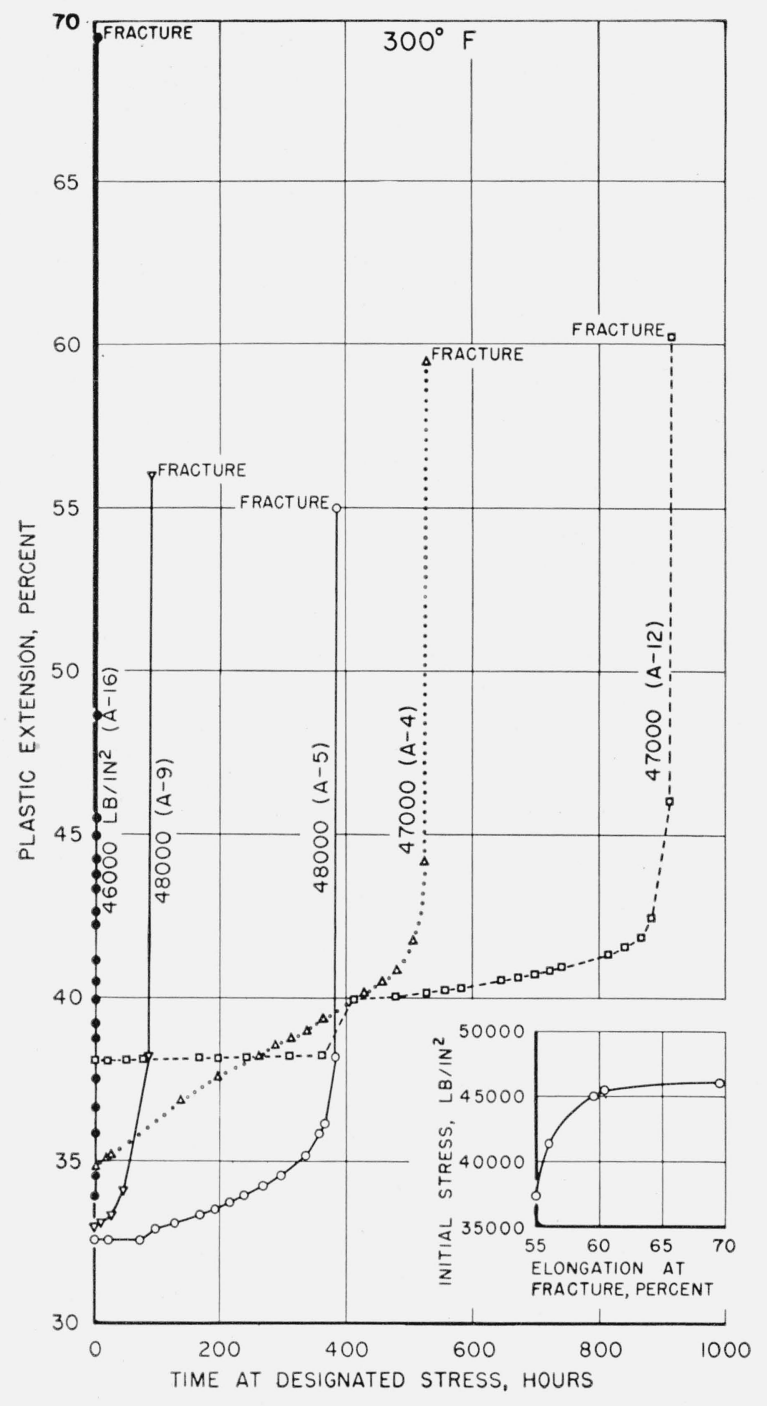

Figure 20. Effect of rate of loading to different stresses on the extension-time curves for specimens fractured at $300^{\circ} \mathrm{F}$.

Refer to tables 1 and 2 and figure 18 for schedule of loading to the designated creep stress.

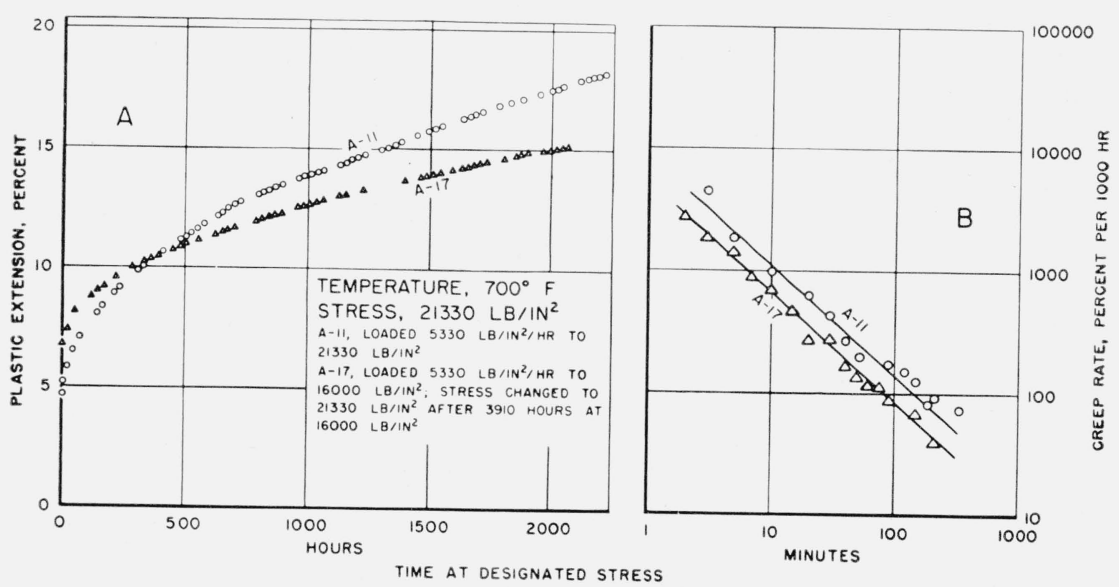

Figure 21. Effect of rate of loading to a stress of 21,330 $\mathrm{lb} / \mathrm{in}^{2}{ }^{2}$ on the extensiontime and creep-rate-time curves for specimens at $700^{\circ} \mathrm{F}$. 


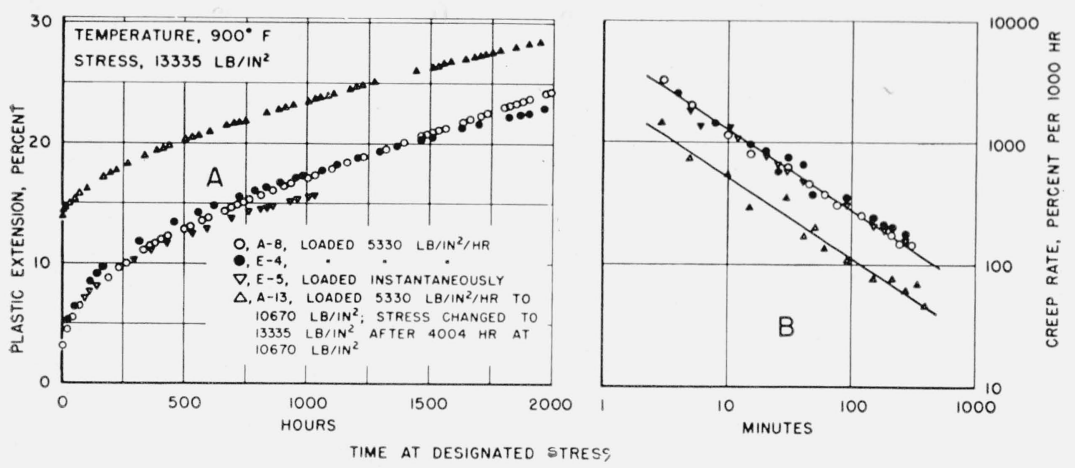

FIGURE 22. Effect of rate of loading to a stress of $13,335 \mathrm{lb} / \mathrm{in}^{2}{ }^{2}$ on the creep characteristics during the first and second stages for specimens at $900^{\circ} F$ and on reproducibility of test results.
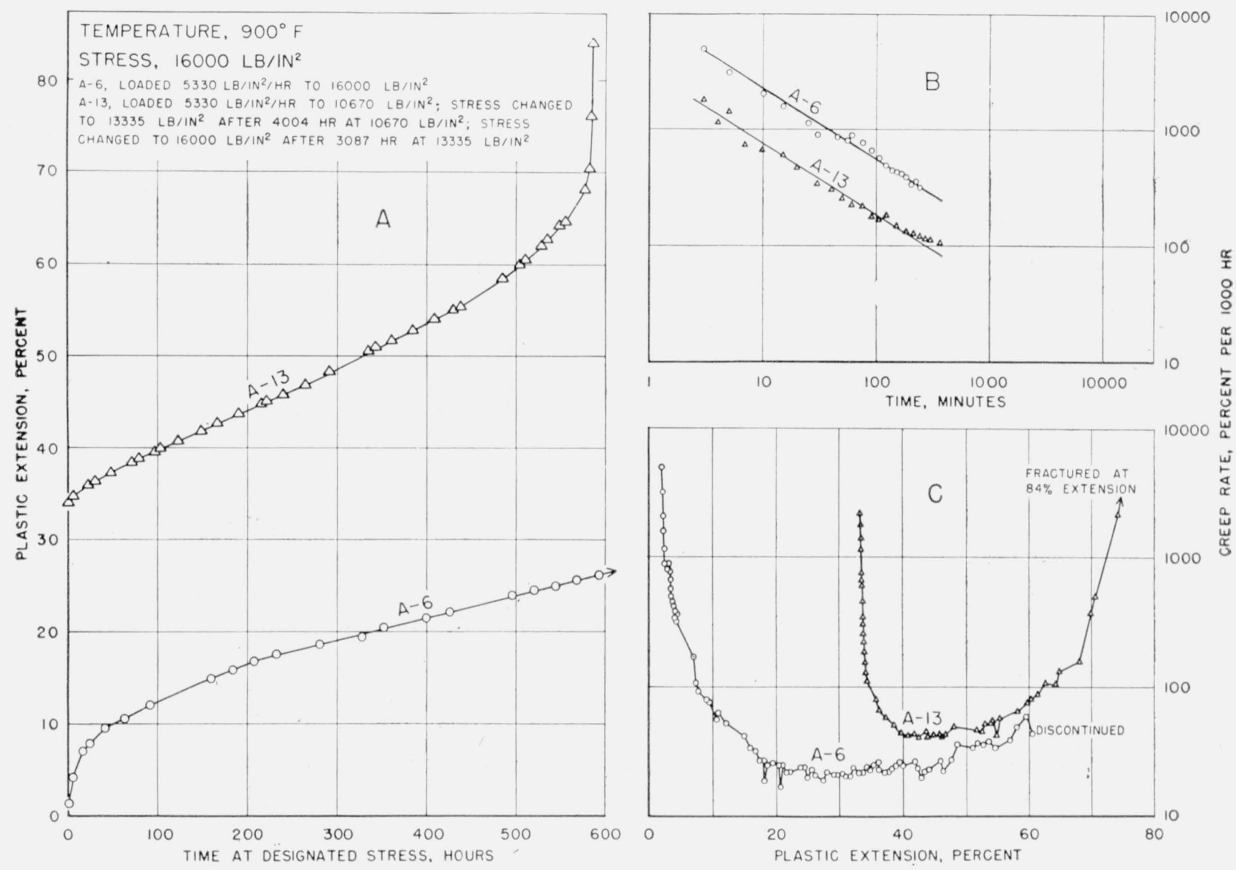

Figure 23. Effect of rate of loading to a stress of $16,000 \mathrm{lb} / \mathrm{in}^{2}{ }^{2}$ on the creep of specimens at $900^{\circ} \mathrm{F}$.

Time values do not include $63.75 \mathrm{hr}$ at zero stress (table 2).
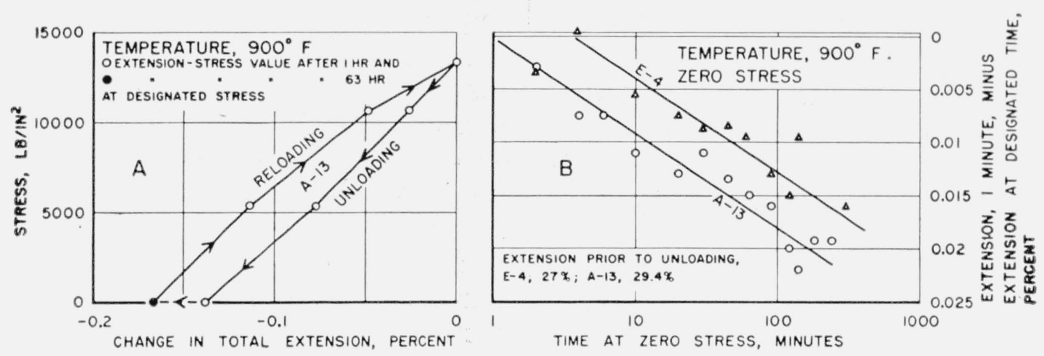

Figure 24. Some relaxation characteristics of the nickel at $900^{\circ} \mathrm{F}$. 
$42,600,45,000,45,500$, or $46,000 \mathrm{lb} /$ in. $^{2}$ (specimens numbered $\mathrm{A}-5, \mathrm{~A}-9, \mathrm{~A}-4, \mathrm{~A}-12$, and $\mathrm{A}-16$, respectively) were attained. Thereafter, the changes in stress were made at the times designated on the curves. If the creep rate, deformation characteristics, and ductility of the high-purity nickel were independent of prior-strain history, then the creep curves would be alike at any one of the selected stress levels. That is, the extension-time curves for all the specimens tested at a selected stress would coincide either as constructed or by the transposition of the initial extension values to those corresponding to the zero time ordinates at this stress. However, an actual comparison of these curves for any selected stress level shows that the creep varied markedly with rate of loading. For example, at a nominal stress of $46,000 \mathrm{lb} / \mathrm{in}^{2}$, specimen $\mathrm{A}-16$, which was loaded relatively rapidly, fractured in $3.66 \mathrm{hr}$, whereas specimen $\mathrm{A}-5$, which was loaded slowly, did not fracture in $3,982 \mathrm{hr}$ at this stress. This difference in creep rate is primarily attributed to a combination of strain-aging and strain-hardening characteristics of the nickel. At $300^{\circ} \mathrm{F}$, the strain aging and hardening is considerably more prominent in the specimens loaded slowly than in the specimens loaded rapidly to the selected creep stresses. Although the tensile strength of the nickel at $300^{\circ} \mathrm{F}$ is 46,400 $\mathrm{lb} / \mathrm{in}^{2}$ [3], it is noteworthy that the creep life was appreciable in some of the specimens tested at stresses in excess of this value.

Lubahn [13] made a review of the literature and discussed the strain-aging effects in both nonferrous and ferrous materials. He relates the effects to yield-point phenomenon, strengthening (increase in flow stress or hardness), discontinuous yielding (serrated stress-strain curves, etc.), and abnormally low rate sensitivity. Furthermore, he reported that strain aging is of particular importance in creep where the associated strengthening can cause a significant decrease in creep rate.

The effect of prior-strain history on creep behavior is evident from the results summarized in figure 18. The time lag for the initiation and propagation of deformation at a fast rate followed by a slowing down to some nearly constant rate can be considered a fundamental property of metals. The sigmoidal form of the extension-time curve obtained with the high-purity nickel, however, may be modified with changes in the strain history of the nickel and in the magnitude of the stress increments. As the stress was increased on a selected specimen, differences were also obtained in the creep rate-time relationship (fig. 19). Each of these curves showed a definite peak, and the maximum creep rate obtained in this family of curves increased with an increase in creep stress.

Extension-time curves are shown in figure 20 for all the specimens tested to complete fracture in creep at $300^{\circ} \mathrm{F}$. The values for time, as plotted in this figure, include only the range after the application of the stress producing fracture, as designated, whereas the extension values also include a summation of all of the prior plastic extension of the specimen. The specimen $(\mathrm{A}-16)$, loaded at the standard rate to $46,000 \mathrm{lb} / \mathrm{in}^{2}$, fractured after a relatively short time at this stress; this creep stress is slightly below that of the tensile strength of the annealed nickel. However, each specimen (A-9, $\mathrm{A}-5, \mathrm{~A}-4$, and $\mathrm{A}-12$ ) that was loaded slowly to a stress in excess of the short-time tensile strength had an appreciable life before fracturing. The plastic extension at fracture of the specimens loaded slowly ranged from about 55 to 60 percent, whereas the extension was 69.5 percent for the specimen loaded rapidly. As shown by the curve in the insert, the elongation at fracture increased continuously with increase in the initial creep stress applied by loading to this stress at $5,330 \mathrm{lb} / \mathrm{in}^{2}$ at 1 -hr intervals.

Extension-time curves are shown in figure 21, A, for two specimens at $700^{\circ} \mathrm{F}$ that were loaded differently to a stress of $21,330 \mathrm{lb} / \mathrm{in}^{2}{ }^{2}$ The greater strain hardening in the specimen $(\mathrm{A}-17)$ loaded slowly resulted in the lowering of the curve and rate in the second stage of creep. In loading each specimen, however, the final increment of stress was sufficient to produce a decrease in creep rate with time in the first stage (fig. 21, B). The parallelism of the two curves indicates that there was no appreciable difference in the mechanism of flow of the two specimens in the first stage of creep.

The influence of rate of loading on the creep behavior of the nickel at $900^{\circ} \mathrm{F}$ is shown by the results of figures 22 and 23 and table 3 . The testing program was extended to include duplicate tests on specimens (A-8 and $\mathrm{E}-4)$ prepared from two different bars processed from the same heat.

The creep characteristics in both the first and second stages were nearly alike for the two specimens prepared from different bars of the annealed nickel and tested under the same conditions, as is shown by the near coincidence of the curves representing the experimental values (fig. $22 \mathrm{~A}$ ).

At a stress of $13,335 \mathrm{lb} / \mathrm{in}^{2}{ }^{2}$, the primary creeprate-time curves are nearly parallel (fig. 22B), but the two curves do not coincide. Likewise, at a stress of $16,000 \mathrm{lb} / \mathrm{in}^{2}$, the curves are again nearly parallel (fig. 23B), but they do not coincide and their slope differs from that of the former curves (fig. 22B). This indicates that the mechanism of deformation in the first stage at $900^{\circ} \mathrm{F}$ is stress dependent, but at a given stress level, the mechanism is primarily independent of the prior-strain history of the nickel.

Although the wide variations used in the rate of loading the specimens to the relatively low creep stress of $13,335 \mathrm{lb} / \mathrm{in}^{2}{ }^{2}$ affected the creep rate in the second stage (fig. $22 \mathrm{~A}$ ), this effect was not as prominent as that obtained at the lower test temperatures. A comparison of the extension-time curves for the period ranging from 750 to $1,050 \mathrm{hr}$ indicates that the creep rate of the specimen ( $\mathrm{E}-5)$ loaded instantaneously was somewhat lower than that of the specimens $(\mathrm{A}-8$ and $\mathrm{E}-4)$ loaded at the standard rate. The creep rates of the latter specimens were also higher than that of specimen $(\mathrm{A}-13)$ loaded slowly. The second-stage creep rate was increased and time to fracture was decreased by decreasing the standard rate of loading to a creep stress of $16,000 \mathrm{lb} / \mathrm{in}^{2}{ }^{2}$ (fig. $23 \mathrm{~A})$. This increase in creep rate and decrease in 
time to fracture can be attributed to a difference in amount of plastic deformation of the specimens at the time of applying the creep stress of $16,000 \mathrm{lb} / \mathrm{in}^{2}$.

A specimen $(\mathrm{A}-13)$ was unloaded from a stress of $13,335 \mathrm{lb} / \mathrm{in}^{2}$ and allowed to relax at zero stress before reloading at the standard rate to the above stress; its temperature was maintained at $900^{\circ} \mathrm{F}$. The hysteresis loop (fig. 24,A) obtained was closed, thus indicating no change in the extension value at the attainment of the final creep-stress level. However, the slopes of the curves for the conditions of unloading and reloading (fig. 24,A) and also for initial loading (fig. 1) were not parallel. The effect of time on change in extension at zero stress for this specimen and another specimen $(\mathrm{E}-4)$ that had been tested in creep to approximately the same extension is shown in figure $24, \mathrm{~B}$. The parallelism of the curves indicates that the mechanism of relaxation was similar for the two specimens. The secondstage creep rate of specimen $\mathrm{A}-13$ (table 2) at a stress of $13,335 \mathrm{lb} /$ in. $^{2}$ was slightly lower after the above cycle of unloading and reloading.

The hysteresis loop previously obtained with oxygen-free high-conductivity copper was not closed [1]. Apparently, both the chemical composition and prior-strain history of the materials affect this phenomenon.

Thus, the influence of rate of loading on creep behavior of the initially annealed nickel depended not only upon the strain, temperature, and stress, but also on the magnitude of the aging, strain hardening, and recovery that occurred in the temperature range investigated. The results again serve to emphasize the importance of controlling the rate of loading in creep testing.

\subsection{Effect of Prestraining in Creep on the Mechanical Properties at Room Temperature}

Tension tests were made at room temperature on specimens prestrained different amounts in creep at $900^{\circ} \mathrm{F}$ and also on specimens prestrained in creep at $700^{\circ}$ or $900^{\circ} \mathrm{F}$ and then annealed at $1,750^{\circ} \mathrm{F}$. The results are summarized in figures 25 and 26 and in table 3 .

The influence of prestraining in creep at $900^{\circ} \mathrm{F}$ on the resistance to flow in tension at room temperature is illustrated by a comparison of the relative positions of the curves of figure 25 . The resistance to the initiation of flow was decreased somewhat by deforming 12 - or 19-percent reduction of area in creep, but the resistance to flow for strains within the range of about 0.02 to 0.3 increased with the amount of prestraining in creep. However, at still higher strains the flow curves intersect for specimens prestrained 12 and 19 percent in creep, respectively.

The yield and tensile strengths increased continuously with the amount of prestraining at $900^{\circ} \mathrm{F}$ (table 3). This increase in the strength properties was accompanied by a corresponding decrease in strain at maximum load, at the beginning, and at complete fracture. The inconsistencies observed in this pattern for the values of true stress at the beginning or at complete fracture can be attributed. to

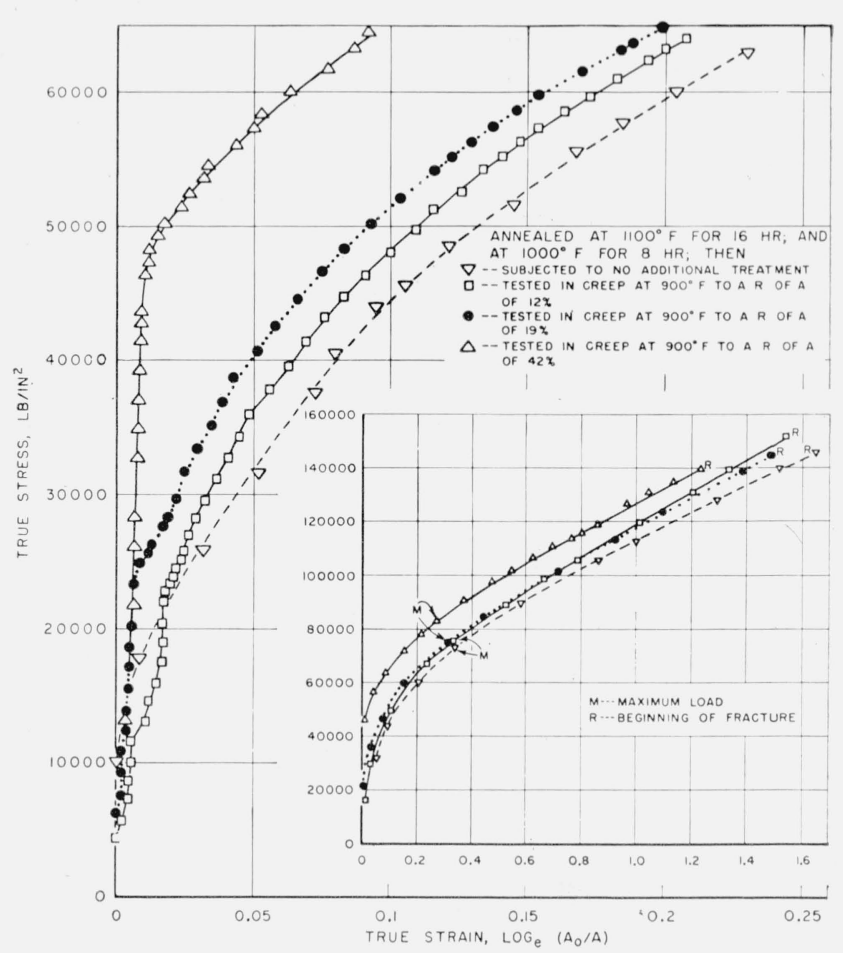

Figure 25. Influence of prior deformation in creep at $900^{\circ} \mathrm{F}$ on the true-stress-true-strain curves for specimens tested in tension at room temperature.

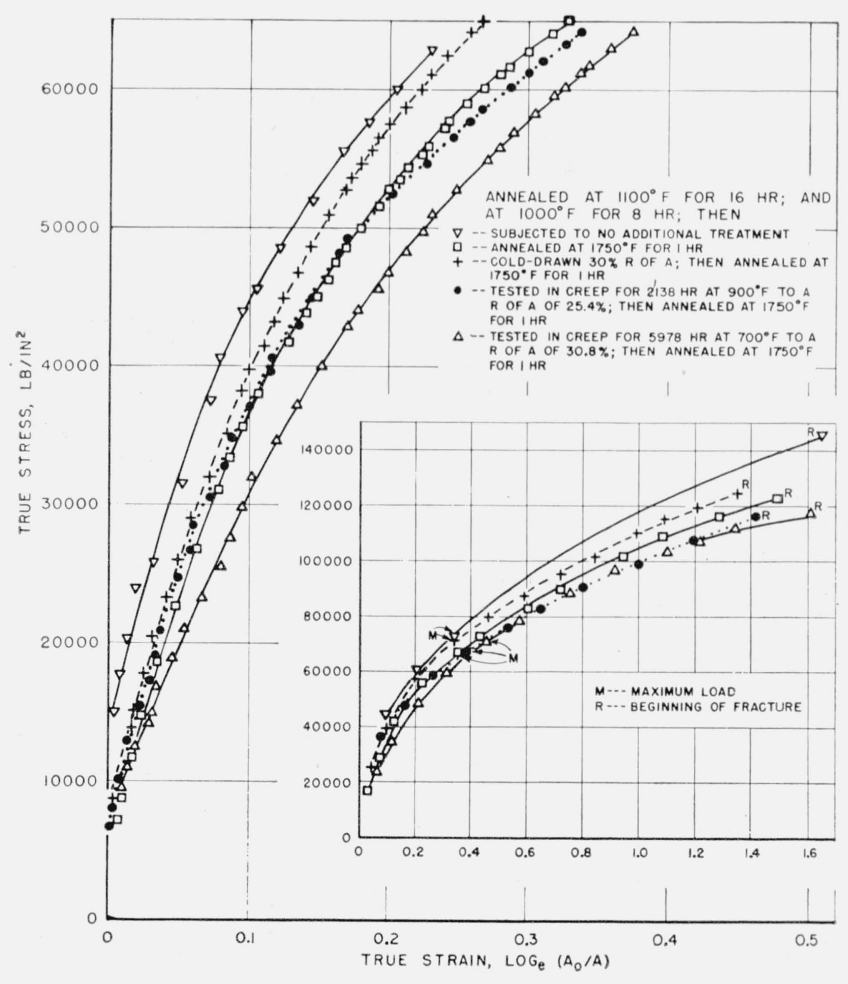

FIGURE 26. Influence of prior-strain history followed by annealing at $1,750^{\circ} \mathrm{F}$ on the true-stress-true-strain curves for specimens tested in tension at room temperature. 
variations in the necking characteristics of the different specimens. The values obtained for reduction of area (total of creep and room temperature tensile) were independent of the prior-strain history.

Increasing the annealing temperature from $1,100^{\circ}$ to $1,750^{\circ} \mathrm{F}$ decreased the resistance to flow at room temperature of the nickel (fig. 26); this increase in annealing temperature was accompanied by an increase in grain size. The resistance to flow at room temperature was further reduced by prestraining a specimen to 30.8-percent reduction of area in creep at $700^{\circ} \mathrm{F}$ before annealing at $1,750^{\circ} \mathrm{F}$ (see table 3 ); this decrease was accompanied by an increase in strain at maximum load. However, prestraining to 25.4-percent reduction of area at $900^{\circ} \mathrm{F}$ followed by annealing at $1,750^{\circ} \mathrm{F}$ did not materially affect the position of the true-stress-true-strain curve for strains ranging up to about 0.3 (maximum load). Above this range, the curves for the two specimens prestrained in creep were nearly alike. The flow curve for the specimen cold-drawn 30-percent reduction of area before annealing at $1,750^{\circ} \mathrm{F}$ is located between the curves for the specimens annealed only at $1,750^{\circ}$ or $1,100^{\circ} \mathrm{F}$. Evidently, the effects of the cold-working, such as preferred orientation and elongation of the grains, were not completely removed by subsequent annealing at the relatively high temperature.

The effects of prestraining the nickel in creep at different temperatures and rates and in tension at room temperature on the necking characteristics and on the Rockwell B hardness at room temperature are shown by the results summarized in figure 27.

It is apparent that the general tendency was for the nickel to neck sharply before fracturing in creep (fig. 27,A) or in tension at room temperature (fig. $27, \mathrm{C})$. However, one specimen $(\mathrm{A}-22)$ with a slow creep rate at $1,200^{\circ} \mathrm{F}$ fractured with a relatively small amount of local necking (fig. 27,A). The necking characteristics observed for the specimens tested at $300^{\circ} \mathrm{F}$ were independent of the rates of loading used (insert, fig. 27,A). For the specimens fractured at room temperature, the tendency toward localized necking was a minimum in the specimen $(\mathrm{C}-9)$ annealed at $1,100^{\circ} \mathrm{F}$ and a maximum in the specimen $(\mathrm{A}-6)$ prestrained to 42 -percent reduction of area in creep at $900^{\circ} \mathrm{F}$ (fig. $27, \mathrm{C}$ ).

The hardness at room temperature of each specimen fractured in creep at $300^{\circ}, 700^{\circ}$, or $900^{\circ} \mathrm{F}$ increased with an increase in the amount of deformation in the vicinity of complete fracture (fig. 27,B). These curves are nearly parallel, but their relative positions varied with the test temperatures and creep rates. The trend was for the curves to be displaced to higher values as the creep temperature was decreased and the creep rate was increased. The hardness of the specimen $(\mathrm{A}-20)$ fractured at $1,200^{\circ} \mathrm{F}$ with a relatively high secondary creep rate of 500 percent per 1,000 hr also increased with increase in deformation at fracture, but the curve was displaced to considerably lower values than the corresponding curves for specimens tested at the lower temperatures. However, the trend was for the hardness of the other two specimens $(\mathrm{A}-21$ and $\mathrm{A}-22)$, tested at $1,200^{\circ} \mathrm{F}$ with slower secondary creep rates, to decrease as the deformation in the vicinity of fracture increased. As previously pointed out, $1,200^{\circ} \mathrm{F}$ is above the recrystallization temperature of nickel. Whether the combination of recrystallization and recovery or strain hardening predominated at $1,200^{\circ}$ $\mathrm{F}$ depended upon the creep rate or time in the third stage of creep. Evidently, strain hardening predominated in the former specimen, whereas recovery and recrystallization predominated in the latter two specimens. The rate of loading at $300^{\circ} \mathrm{F}$ had no material effect on the subsequent hardness induced by deforming in tension at room temperature.

As is to be expected, the hardness of all the specimens tested in tension at room temperature increased continuously with increase in deformation (fig. 27,D). However, the relative positions of the hardnessreduction-of-area curves varied with the prior-strain history of the nickel. Prestraining in creep at $900^{\circ}$ $\mathrm{F}$, without subsequent annealing, resulted in a general trend of raising the positions of these curves as the amount of prestraining increased. Increasing the annealing temperature from $1,100^{\circ}$ to $1,750^{\circ} \mathrm{F}$ had no significant effect on the hardness-reduction-ofarea relationship at room temperature (specimens $\mathrm{C}-9$ and $\mathrm{A}-19$, respectively). This relationship was also unaffected by cold-drawing 30 -percent reduction of area followed by annealing at $1,750^{\circ} \mathrm{F}$ (specimens $631-A$ and $A-19$, respectively). However, prestraining a specimen to 30.8-percent reduction of area into the third stage of creep at $700^{\circ} \mathrm{F}$ before annealing at $1,750^{\circ} \mathrm{F}$ had the over-all effect of decreasing the resistance to hardening induced by deforming in tension at room temperature (specimens $\mathrm{A}-17$ and 631-A).

\subsection{Effect of Creep Conditions on Fracture Characteristics and Structures}

The effect of temperature on the appearance of the specimens fractured in creep at relatively high rates is illustrated in figure 28 . Each of these specimens exhibited a ductile fracture, a rim effect, and both circumferential and longitudinal flow lines on the surface. No evidence of surface cracking was observed in the specimens fractured at $300^{\circ}$ or $700^{\circ}$ $\mathrm{F}$, whereas numerous cracks were formed in the surface of the specimens fractured at $900^{\circ} \mathrm{F}$. Surface cracking was accentuated by further increasing the test temperature to $1,200^{\circ} \mathrm{F}$ (fig. $29, \mathrm{~A}$ ) and by decreasing the creep rate at this temperature (fig. 29). The presence of numerous surface cracks, however, was not always accompanied by brittle behavior, as determined by the appearance of flow lines and by a measurement of the reduction of area at fracture. This is evident by a comparison of the appearance of the specimens tested at the fast or intermediate creep rate at $1,200^{\circ} \mathrm{F}$ (fig. $29, \mathrm{~A}$ and $\mathrm{B}$ ) with that of the specimens tested at high creep rates at $300^{\circ}$ or $700^{\circ} \mathrm{F}$ (fig. 28, A and B). Despite the presence of the surface cracks in the former specimens, it is believed that the cracks linking up to form complete rupture were initiated at or near the axis of the 


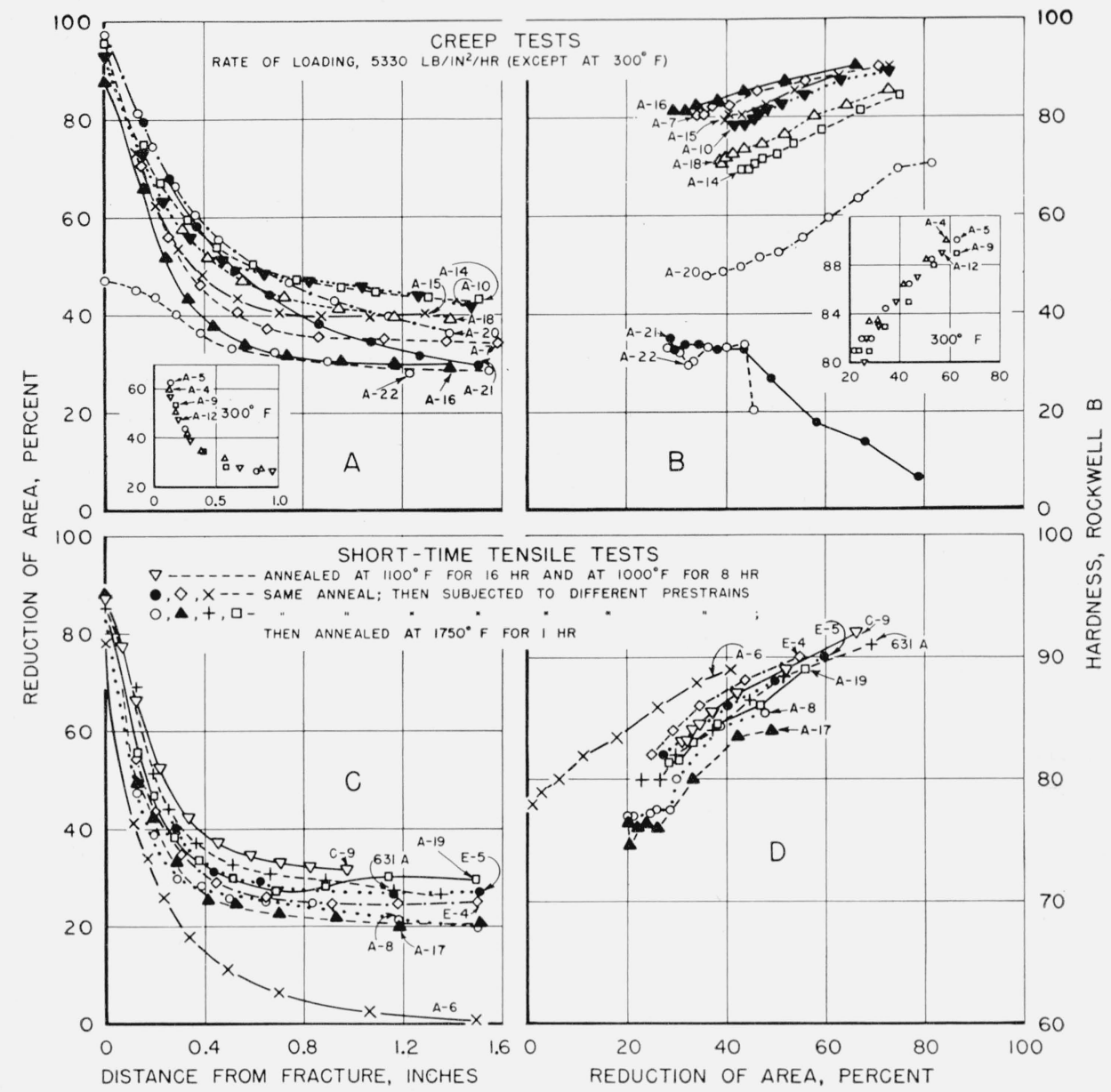

FIGURE 27. Effects of temperature, prior-strain history, and creep rate on specimen contour and distribution of hardness of specimens fractured in creep or in tension at room temperature.

\begin{tabular}{|c|c|c|c|c|c|c|}
\hline \multicolumn{3}{|c|}{ Creep (A and B) } & \multicolumn{4}{|c|}{ Tensile (C and D) } \\
\hline \multirow[b]{2}{*}{ Specimen } & \multirow{2}{*}{$\begin{array}{c}\text { Tempera- } \\
\text { ture }\end{array}$} & \multirow{2}{*}{$\begin{array}{l}\text { Second- } \\
\text { stage creep } \\
\text { rate }\end{array}$} & \multirow[b]{2}{*}{ Specimen } & \multicolumn{2}{|c|}{ Creep test } & \multirow{2}{*}{$\begin{array}{l}\text { Additional thermal treatment prior to ten- } \\
\text { sile test }\end{array}$} \\
\hline & & & & $\begin{array}{c}\text { Tempera- } \\
\text { ture }\end{array}$ & $\begin{array}{l}\text { Reduction } \\
\text { of area }\end{array}$ & \\
\hline 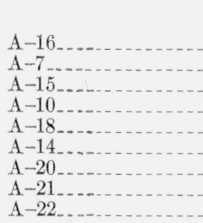 & $\begin{array}{r}\circ F \\
300 \\
700 \\
700 \\
700 \\
900 \\
900 \\
1,200 \\
1,200 \\
1,200\end{array}$ & $\begin{array}{c}\% / 1,000 \mathrm{hr} \\
2100 \\
1020 \\
120 \\
33.3 \\
620 \\
238 \\
500 \\
62.5 \\
10.5\end{array}$ & $\begin{array}{l}\mathrm{C}-9 \ldots \ldots \\
\mathrm{E}-5 \ldots \\
\mathrm{E}-4 \ldots \\
\mathrm{A}-6 \ldots \\
\mathrm{A}-19 \\
631-\mathrm{A} \\
\mathrm{A}-8 \\
\mathrm{~A}-17\end{array}$ & \begin{tabular}{c}
$\circ F$ \\
None \\
900 \\
900 \\
900 \\
None \\
\hdashline do . ... \\
900 \\
700
\end{tabular} & $\begin{array}{l}\text { \% } \\
\text { None } \\
12 \\
19 \\
42 \\
\text { None } \\
\text { do_... } \\
25.4 \\
30.8\end{array}$ & $\begin{array}{l}\text { None. } \\
\text { Do. } \\
\text { Do. } \\
\text { Do. } \\
\text { Annealed at } 1,750^{\circ} \mathrm{F} \text {. } \\
\text { Annealed at } 1,750^{\circ} \mathrm{F} \text { after cold-drawing } 30 \% \\
\text { reduction of area. } \\
\text { Annealed at } 1,750^{\circ} \mathrm{F} \text {. } \\
\text { Do. }\end{array}$ \\
\hline
\end{tabular}

See table 2 for rate of loading of specimens $\mathrm{A}-4$. A-5, A-9, and $\mathrm{A}-12$.

specimen and then propagated outward to the surface (rim effect). However, extensive surface cracking and a relatively brittle fracture were obtained in the specimen tested at a slow creep rate at $1,200^{\circ} \mathrm{F}$ (fig. 29,C). The evidence indicates that cracking started at or near the surface of this specimen and then propagated to its axis. Thus, the surface appearance of a failed specimen does not necessarily reveal its behavior in creep.
The grains were nearly equiaxed in the annealed nickel (fig. 30,A). These grains were elongated during creep, but the degrees of distortion and strain markings vary with the test temperature and creep rates. The trend was for the distortion and strain markings in the region of complete fracture to be accentuated by decreasing the secondary creep rate within the range used at $700^{\circ}$ or $900^{\circ} \mathrm{F}$ (fig. 30,C, D, $\mathrm{E}$, and F). Distortion of the grains at fracture was 
somewhat less severe in the specimen tested at $300^{\circ}$ $\mathrm{F}$ at a relatively high rate (fig. $30, \mathrm{~B}$ ) than in the specimens fractured at either $700^{\circ}$ or $900^{\circ} \mathrm{F}$. Furthermore, the number of microcracks observed in the vicinity of complete fracture was a minimum in the specimens fractured at $300^{\circ} \mathrm{F}$, intermediate at $900^{\circ} \mathrm{F}$, and a maximum at $700^{\circ} \mathrm{F}$. If cracks of microscopic dimension are a prerequisite for the beginning of the third stage, then it is to be expected that cracks also would be observed in regions other than at complete fracture. However, no microcracks were detected in these nickel specimens fractured in creep except in the region of complete fracture.

No indication of recrystallization was observed in a metallographic study of the specimens fractured at $300^{\circ}, 700^{\circ}$, or $900^{\circ} \mathrm{F}$; the failures were probably transcrystalline.

Strain marking and distortion of the grains at fracture were less prominent in the specimens tested
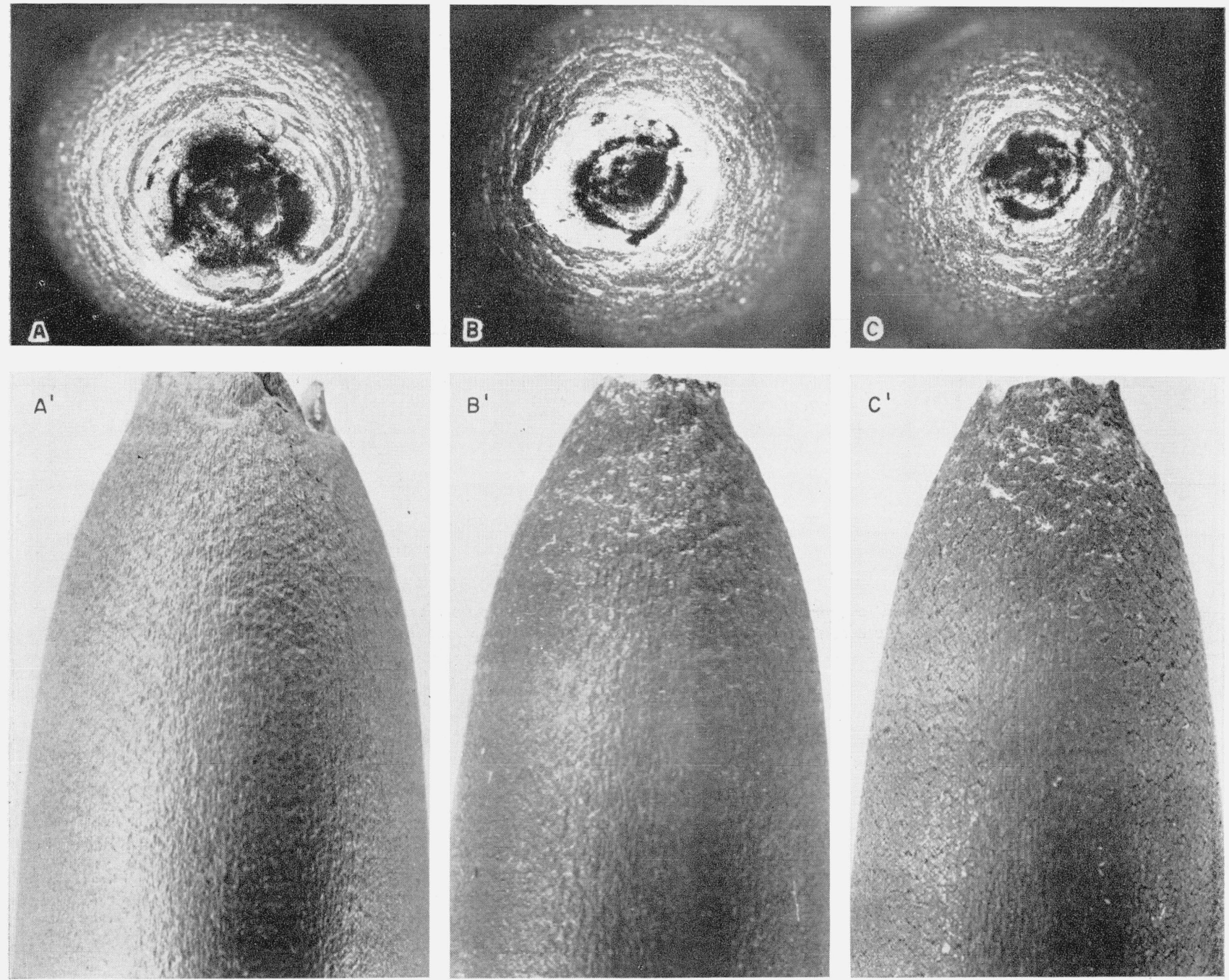

FiguRE 28. Specimens fractured in creep at different temperatures.

Unetched, $\times 6$.

\begin{tabular}{|c|c|c|c|c|}
\hline & \multicolumn{2}{|c|}{ Test } & \multirow{2}{*}{$\begin{array}{l}\text { Plastic ex- } \\
\text { tension in } \\
2 \text { in. }\end{array}$} & \multirow{2}{*}{$\begin{array}{l}\text { Reduction } \\
\text { of area }\end{array}$} \\
\hline & $\begin{array}{l}\text { Tempera- } \\
\text { ture }\end{array}$ & Rate & & \\
\hline $\begin{array}{l}\mathrm{A}, \mathrm{A}^{\prime}, \ldots \\
\mathrm{B}, \mathrm{B}^{\prime}, \mathrm{C}^{\prime}, \ldots\end{array}$ & $\begin{array}{l}\circ F \\
300 \\
700 \\
900\end{array}$ & $\begin{array}{c}\% / 1,000 \mathrm{hr} \\
2,100 \\
1,020 \\
620\end{array}$ & $\begin{array}{c}\% \\
69.5 \\
73 \\
102.5\end{array}$ & $\begin{array}{c}\% \\
87.6 \\
92.9 \\
95.9\end{array}$ \\
\hline
\end{tabular}


at $1,200^{\circ} \mathrm{F}$ (fig. 31) than in the specimens fractured at the lower temperatures (fig. 30). Moreover, the size of the grains at $1,200^{\circ} \mathrm{F}$ varied appreciably with creep rate and also from surface to center in one specimen. Decreasing the secondary creep rate from 500 percent to 10.5 percent per $1,000 \mathrm{hr}$ was accompanied by an appreciable increase in grain size and a general deterioration at fracture (fig.
$31, A$ and $B$ ). The grain size in the vicinity of fracture of the latter specimen varied markedly from its center to its surface (fig. 31,B and C, respectively). This may be interpreted as supporting the belief that the final fracture was initiated at or near the surface (large grains) and then propagated to the axis (small grains). As $1,200^{\circ} \mathrm{F}$ is above the recrystallization temperature of nickel, it seems feasible
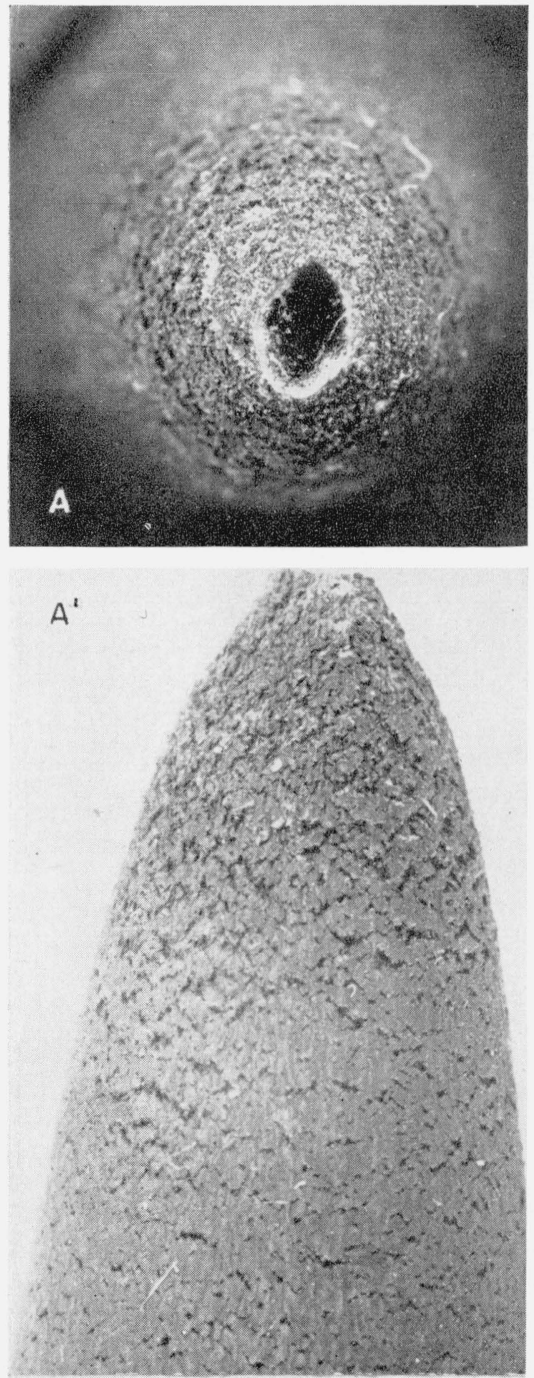

$500 \%$
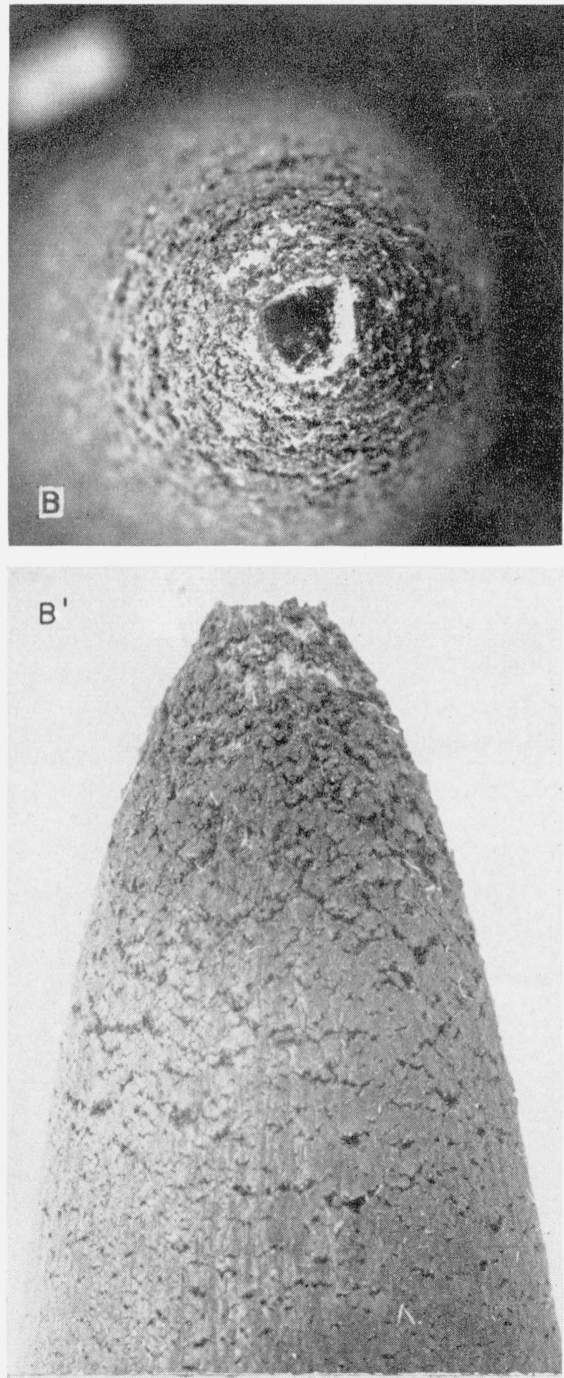

$62.5 \%$

TEMPERATURE, $1200^{\circ} \mathrm{F}$
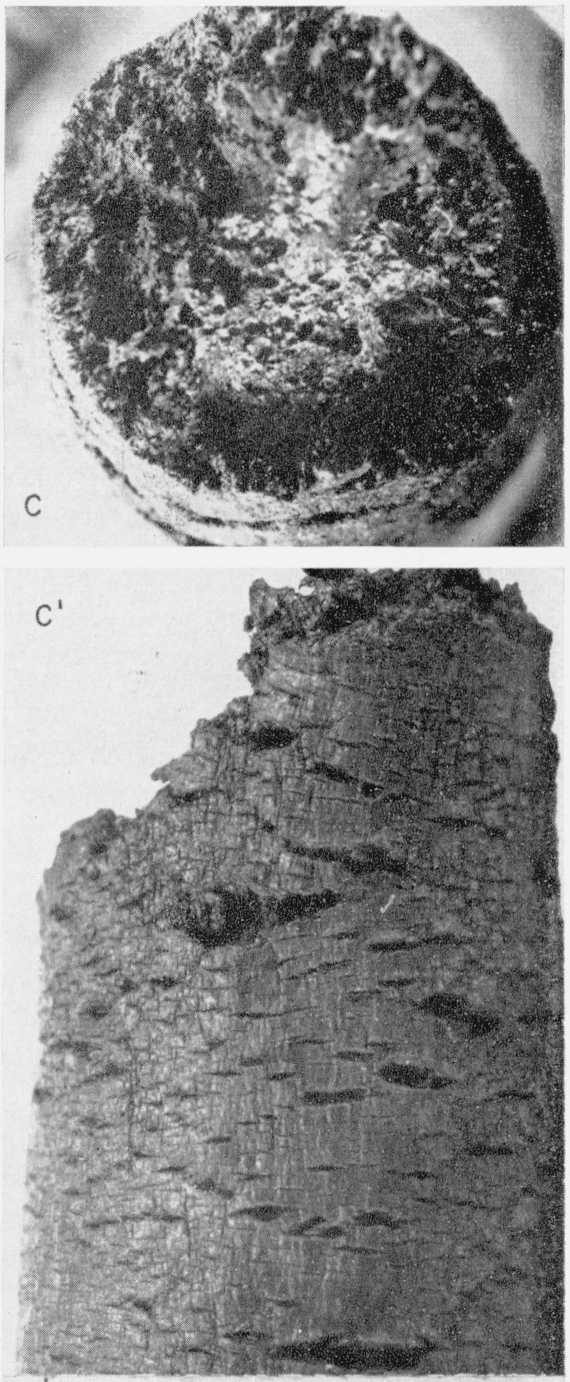

$10.5 \% / 1000 \mathrm{HR}$

FiguRE 29. Specimens fractured at $1,200^{\circ} \mathrm{F}$ at different rates.

Unetched, $\times 6$.

\begin{tabular}{|c|c|c|c|}
\hline & Creep rate & $\begin{array}{c}\text { Plastic ex- } \\
\text { tension in } \\
2 \mathrm{in.}\end{array}$ & $\begin{array}{c}\text { Reduction } \\
\text { of area }\end{array}$ \\
\cline { 1 - 2 } & & & \\
\cline { 1 - 2 } $\mathrm{A}, \mathrm{A}^{\prime}$ & $\% / 1,000 \mathrm{hr}$ & $\%$ & $\%$ \\
$\mathrm{~B}, \mathrm{~B}^{\prime}$ & 500 & 91 & 97.4 \\
$\mathrm{C}, \mathrm{C}^{\prime}$ & 62.5 & 87 & 98.1 \\
& 10.5 & 66 & 47.1 \\
\hline
\end{tabular}



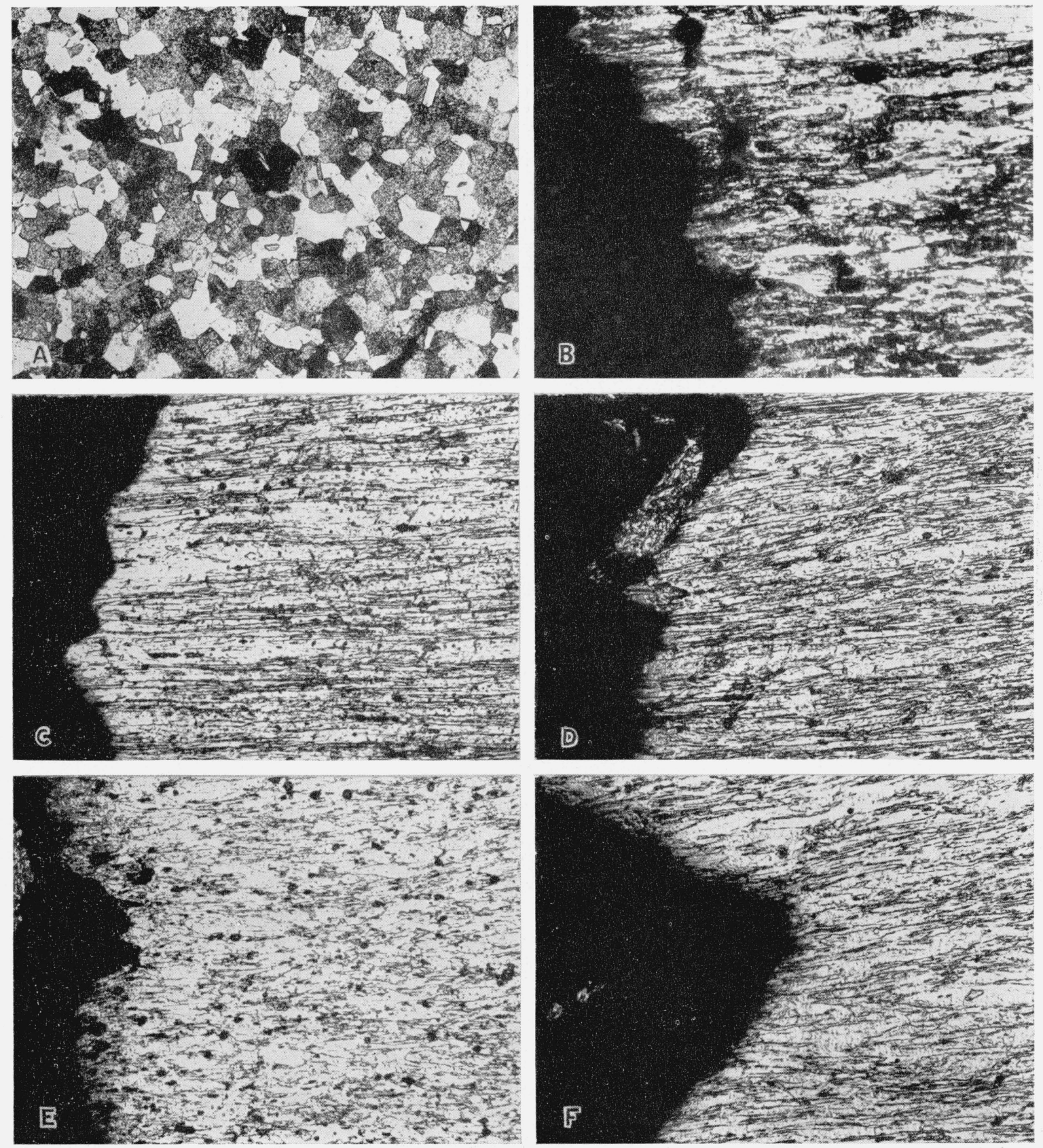

FIGURE 30. Structure of the nickel as annealed and after fracturing in creep at different temperatures and rates.

Longitudinal sections etched in 6 parts of $\mathrm{HNO}_{3}$ (concentrated) and 4 parts of glacial ascetic acid.

\begin{tabular}{|c|c|c|c|c|c|}
\hline & \multicolumn{2}{|c|}{ Test } & \multirow{2}{*}{$\begin{array}{l}\text { Plastic ex- } \\
\text { tension in } \\
2 \text { in. }\end{array}$} & \multirow{2}{*}{$\begin{array}{l}\text { Reduction } \\
\text { of area }\end{array}$} & \multirow{2}{*}{ Remarks } \\
\hline & $\begin{array}{l}\text { Tempera- } \\
\text { ture }\end{array}$ & Creep rate & & & \\
\hline A & ${ }^{\circ} F$ & $\% / 1,000 \mathrm{hr}$ & $\%$ & $\%$ & \multirow{6}{*}{$\begin{array}{l}\times 75 \text {; as annealed. } \\
\times 100 ; \text { near axis at fracture } \\
\text { Do. } \\
\text { Do. } \\
\text { Do. } \\
\text { Do. }\end{array}$} \\
\hline B & 300 & 2,100 & 69.5 & 87.6 & \\
\hline c & 700 & & 91 & 93.4 & \\
\hline I & 700 & 33.3 & 99.5 & 92.3 & \\
\hline $\mathrm{F}$ & 900 & 620 & 102.5 & 95.9 & \\
\hline $\mathrm{H}$ & 900 & 238 & 107.5 & 95.8 & \\
\hline
\end{tabular}


that the freshly fractured and nearly strain-free recrystallized grains at the surface continued to grow while the normal process of strain hardening, recovery, and recrystallization was occurring in the unfractured interior of the specimen. The relatively rapid grain growth after the final recrystallization is even more apparent at the surface 0.1 in. from complete fracture of this specimen (fig. 31,D).
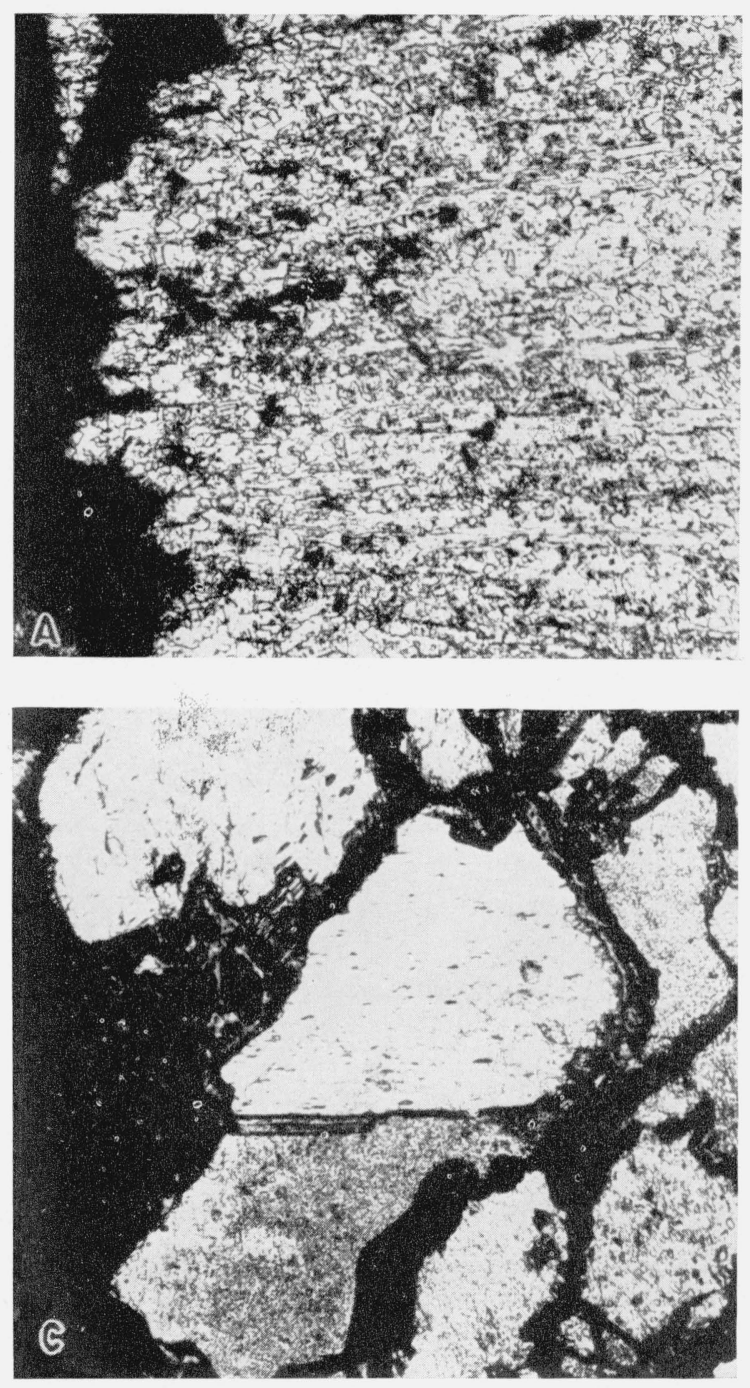

The fractures at $1,200^{\circ} \mathrm{F}$ appeared predominantly intercrystalline, although some transcrystalline cracking was observed.

Typical microstructures observed in a specimen taken from a test bar that had been strained into the third stage of creep at $900^{\circ} \mathrm{F}$ and then fractured in tension at room temperature are illustrated in the photomicrographs of figure 32 . The microcracks
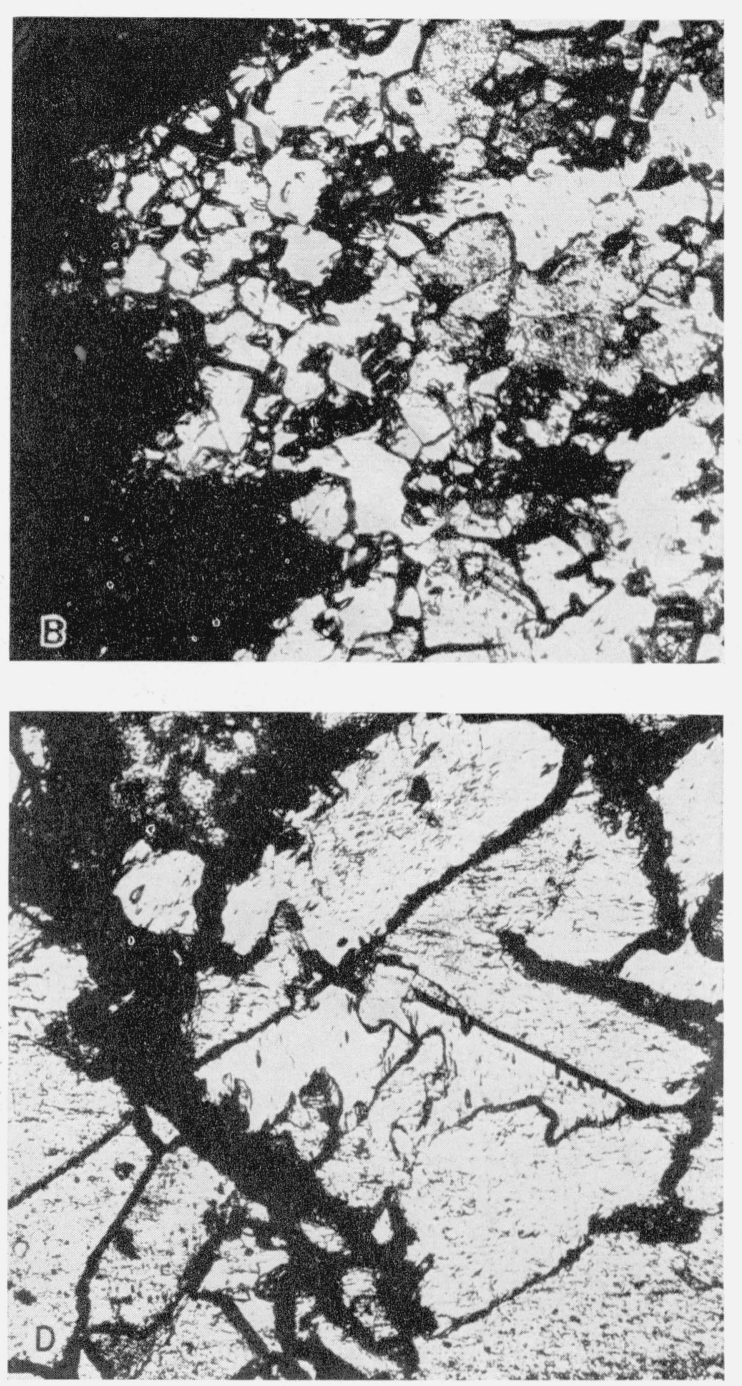

FIGURE 31. Structure of the nickel after fracturing in creep at different rates at $1,200^{\circ} \mathrm{F}$.

Longitudinal sections etched in 6 parts of $\mathrm{HNO}_{3}$ (concentrated) and 4 parts of glacial acetie acid. $\times 100$.

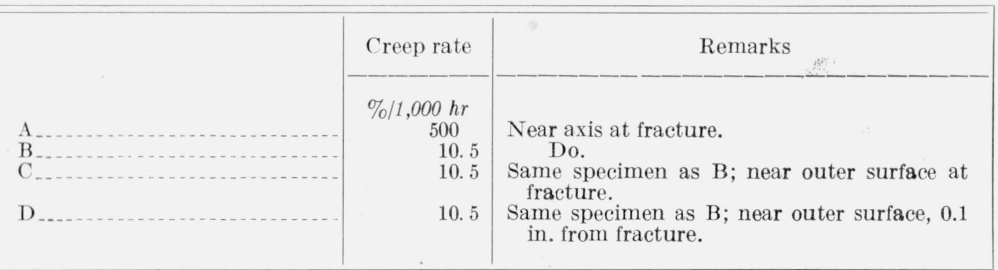


were located near the axis of the specimen, and they were confined principally within the region of complete fracture; the cracks were of the elliptical type. The extensive flow that occurred at the outer surface and the general disintegration at the axis of the specimen indicate that the cracking leading to complete rupture was initiated at the center and then progressed outward. An oxide film formed on the specimen during the time of exposure in air at $900^{\circ} \mathrm{F}$. This film was fractured in the tension test at room temperature (fig. 32,C and D), but apparently it had no significant effect on the mechanism of the final fracture. Extensive strain markings and some distortion of the parent grains are also evident some distance from complete fracture (fig. 32,E and F).

In a specimen that was strained into the third
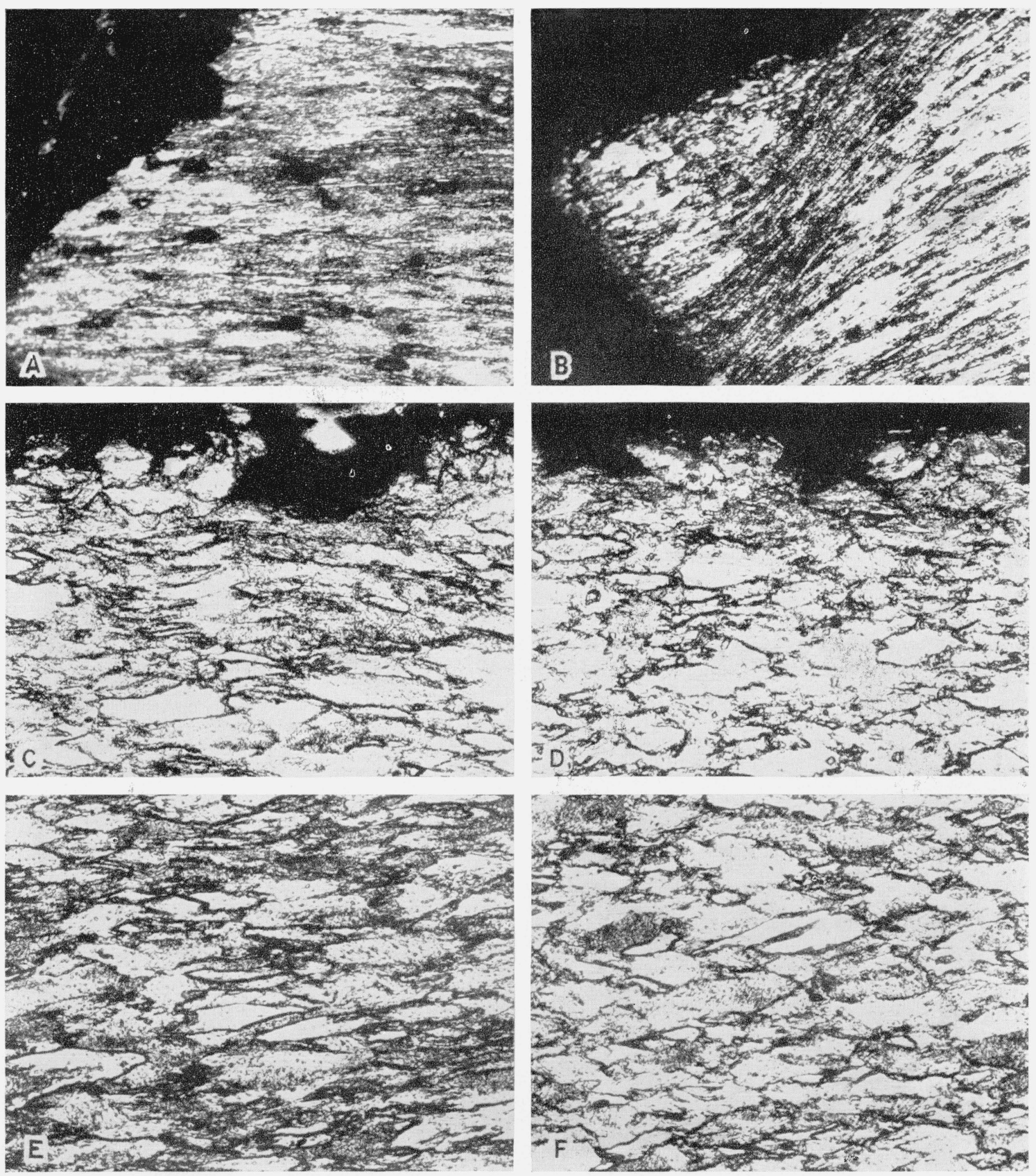

FIGURE 32. Structure of a specimen strained in creep at $900^{\circ} \mathrm{F}$ and then fractured in tension at room temperature.

Longitudinal sections, etched in 6 parts of concentrated nitric and 4 parts ${ }^{\circ}$ of glacial acetic acids. $\times 100$.

A, Near axis at fracture; B, near outer surface at fracture; $\mathrm{C}$, near outer surface $0.1 \mathrm{in}$. from fracture; D, near outer surface $0.3 \mathrm{in}$. from fractu re; $\mathrm{E}$, near axis 0.1

in. from fracture; $F$, near axis 0.3 in. from fracture. 
stage of creep at $700^{\circ}$, then annealed at $1,750^{\circ} \mathrm{F}$ before fracturing in tension at room temperature, the fracture was transcrystalline (fig. 33,A). The pronounced elongation of the grains at the outer surface and the intensification of strain marking within these grains (fig. 33,B) also indicate that the fracture of this specimen started at or near the axis and propagated outward. It is of interest to note that no general disintegration occurred in this specimen and the wavy strain markings or bands become wider as the distance from complete fracture is increased up to 0.3 in. (fig. $33, A, C$, and D). Some of the strain markings also cross the grain boundaries, as is clearly illustrated in figure $33, \mathbf{C}$.
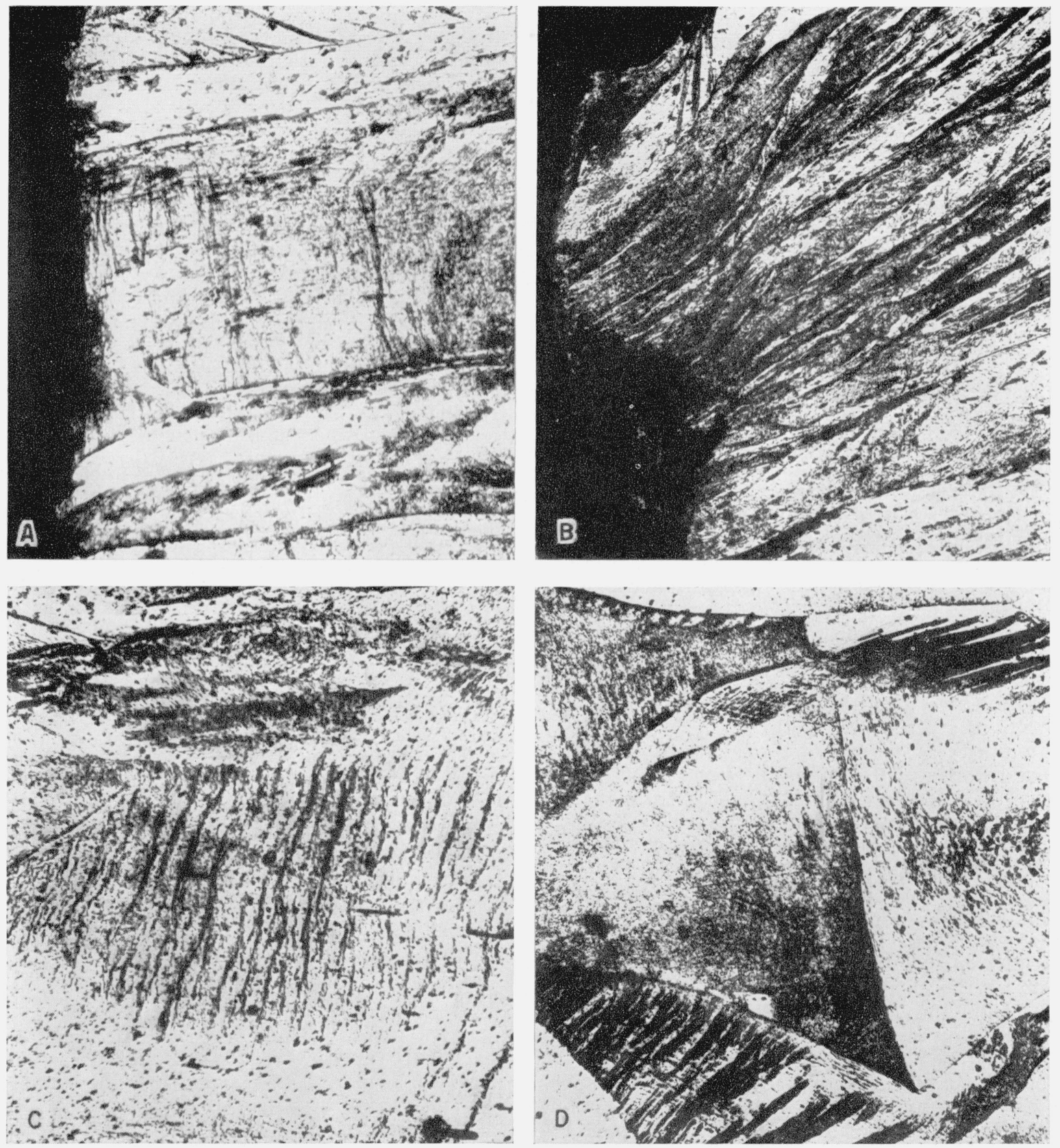

FIgURE 33. Effect of intermediate annealing at $1,750^{\circ} \mathrm{F}$ on the structure of a specimen previously extended in creep at $700^{\circ} \mathrm{F}$ and subsequently fractured in tension at room temperature.

Longitudinal sections etched in 6 parts of concentrated nitric and 4 parts of glacial acetic acid. $\times 100$

A, Near axis at fracture; $B$, near outer surface at fracture: $C$, near axis 0.1 in. from fracture; $D$, near axis 0.3 in. from fract ure. 


\section{Summary}

Tests were made to determine the influence of stress, temperature, and prior-strain history on the creep behavior of initially annealed high-purity nickel. An evaluation was also made of the effect of prestraining in creep, with and without subsequent annealing, on the hardness and tensile properties at room temperature. A metallographic study was made of all the specimens fractured in creep and of specimens fractured in tension at room temperature after prestraining in creep. The results are summarized in figures and tables and discussed in some detail in the text.

Discontinuous flow was observed in creep at $300^{\circ}$, $700^{\circ}, 900^{\circ}$, and $1,200^{\circ} \mathrm{F}$. The magnitude and position of the serrations in the creep-rate-extension curves varied with the test temperatures, and they were affected by such factors as strain aging, strain hardening, recovery, Curie-point behavior, recrystallization, and grain growth.

The experimental values for primary creep agreed fairly closely with the results predicted by the theory of exhaustion and generation of dislocations as proposed by Mott and Nabarro and modified by others.

Although the resistance of the nickel to creep increased as the test temperature decreased, the resistance was especially high at a temperature of $300^{\circ} \mathrm{F}$. This high resistance is attributed to a combination of strain aging and age hardening and relatively low rate of recovery. The phenomenon of strain aging was especially prominent in the creep tests carried out at $300^{\circ} \mathrm{F}$. Nonlinear relations were generally obtained between the stress and secondary creep rate when the experimental values were plotted on $\log -\log$ or semilog (log of rate) bases. Moreover, the second-stage creep rate was not a consistent index to the ductility of the nickel at the beginning of the third stage of creep or at fracture.

The ductility at fracture was relatively high for all creep conditions except for one specimen that showed evidence of brittle behavior. This specimen was tested at $1,200^{\circ} \mathrm{F}$ at a slow secondary creep rate, and it showed a general deterioration at the time of fracture. Internal disintegration was confined to the region of complete fracture in all the specimens tested in creep at $300^{\circ}, 700^{\circ}$, or $900^{\circ} \mathrm{F}$, and the fractures were preceded by appreciable necking. Cracks of microscopic dimensions were not a prerequisite for the initiation of the third stage of creep.

The yield and tensile strengths of specimens tested in tension at room temperature increased with the amount of prestraining in creep at $900^{\circ} \mathrm{F}$. This increase in strength properties at room temperature was accompanied by a decrease in elongation, whereas the total reduction of area was independent of the prior-strain history.
The Rockwell B hardness at room temperature of each specimen fractured in creep at $300^{\circ}, 700^{\circ}$, or $900^{\circ} \mathrm{F}$ increased with an increase in deformation in the vicinity of complete fracture. This trend was also observed in a specimen tested at a relatively high secondary creep rate at $1,200^{\circ} \mathrm{F}$, but with slower rates at this temperature, the hardness decreased as the deformation increased in the vicinity of fracture.

Recrystallization occurred in the specimens fractured in creep at $1,200^{\circ} \mathrm{F}$; in some cases, recrystallization was accompanied by grain growth. However, no evidence of recrystallization was detected in a metallographic study of all the specimens fractured in creep at the lower temperatures. The fractures appeared to be predominantly transcrystalline at $300^{\circ}, 700^{\circ}$, or $900^{\circ} \mathrm{F}$ and intercrystalline at $1,200^{\circ} \mathrm{F}$.

The prior-strain history of the nickel also had a very marked effect on the second-stage creep rate, and the experimental results again serve to emphasize the importance of controlling the rate of loading in creep testing.

\section{References}

[1] William D. Jenkins and Thomas G. Digges, Creep of high-purity copper, J. Research NBS 45, 153 (1950) RP2121.

[2] William D. Jenkins and Thomas G. Digges, Creep of annealed and cold-drawn high-purity copper, J. Research NBS 47, 272 (1951) RP2254.

[3] William D. Jenkins and Thomas G. Digges, Effect of temperature on the tensile properties of high-purity nickel, J. Research NBS 48, 313 (1952) RP2317.

[4] William D. Jenkins and Thomas G. Digges, Influence of prior strain history on the tensile properties and structures of high-purity copper, J. Research NBS 49, 167 (1952) RP2354.

[5] M. W. Nathans, E. L. Parker, and T. H. Hazlett, A survey of theories of creep of metals, First Technical Report Under U. S. Atomic Energy Commission Contract AT-11-1-Gen 10, Project 1 (Nov. 15, 1949).

[6] A. D. Schwope and L. R. Jackson, A survey of creep in metals, NACA Tech. Note 2516 (Nov. 1951).

[7] T. H. Hazlett and E. R. Parker, Nature of the creep curve, J. Metals 5, 318 (Feb. 1953).

[8] Metals Handbook, 1047 (1948)

[9] W. Köster, Die Temperaturabhängigkeit des Elastizitätsmoduls reiner Metalle, Z. Metallkunde $\mathbf{3 9}, 1$ (1948).

[10] N. F. Mott and F. R. N. Nabarro, Dislocation theory and transient creep, Report of a Conference on Strength of Solids, Phys. Soc. p. 1 (1948).

[11] E. N. da C. Andrade, The creep of metals, Report of a Conference on Strength of Solids, Phys. Soc., p. 20 (1948).

[12] M. Davis and N. Thompson, Creep in a precipitationhardened alloy, Proc. Phys. Soc. [B] 63, 847 (1950).

[13] J. D. Lubahn, Strain aging effects, Trans. Am. Soc. Metals 44, 643 (1952).

Washington, May 26, 1954. 